Review

\title{
An Overview of Bioplastic Research on Its Relation to National Policies
}

\author{
Ricard Garrido $^{1}$, Luisa F. Cabeza ${ }^{1, *(D)}$ and Victor Falguera ${ }^{2}$ (D) \\ 1 GREiA Research Group, Universitat de Lleida, Pere de Cabrera s/n, 25001 Lleida, Spain; \\ ricard.garrido@udl.cat \\ 2 AKIS International, c/Dr. Robert 33, 25171 Albatàrrec, Spain; v.falguera@akisinternational.com \\ * Correspondence: luisaf.cabeza@udl.cat
}

Citation: Garrido, R.; Cabeza, L.F.;

Falguera, V. An Overview of

Bioplastic Research on Its Relation to

National Policies. Sustainability 2021,

13, 7848. https://doi.org/10.3390/

su13147848

Academic Editors:

Muhammad Asif Khan,

Gyuricza Csaba and Judit Oláh

Received: 8 June 2021

Accepted: 8 July 2021

Published: 14 July 2021

Publisher's Note: MDPI stays neutral with regard to jurisdictional claims in published maps and institutional affiliations.

\begin{abstract}
There is an increasing concern about fossil energy and products derived from it. The plastic industry depends on oil, and produced plastics cannot degrade naturally. An alternative to plastics from oil is the use of bioplastics, which can be degradable. The bibliometric study of the publications related to bioplastics carried out in this paper shows that research on this topic is growing both in developed (USA, European Union, and Canada) and in developing countries (China, India, Thailand, and Malaysia), mostly following the implementation of bioeconomy standards and labels by their governments. The main authors and the collaborations they have worldwide are also presented here. The research carried out in this paper is not only devoted to technological aspects but also to economic aspects and inhabitant ratios. Trends in publications, by country and authors, are analyzed. Finally, this paper also studies the countries governmental policies and how they impact the bioplastic field.
\end{abstract}

Keywords: bioplastic; climate change; bibliometric analysis; knowledge mapping; trends; gaps; bioeconomy

\section{Introduction}

Plastics made from fossil-derived synthetic polymers have posed serious problems for the environment. Current approaches to production, use, and disposal are not sustainable and present concerns for wildlife and human health. Concerns about use and disposal are diverse and include the accumulation of waste in landfills and in natural habitats, physical problems for wildlife resulting from ingestion or entanglement in plastic, the leaching of chemicals from plastic products, and the potential for plastics to transfer chemicals to wildlife and humans [1].

Bioplastics may offer benefits relative to fossil-based plastics; the new generation of plastic products made from renewable feedstock, the ability of biodegradability, compostability, and the evaluation measured by life cycle analysis (LCA) should be all taken into account to evaluate the contribution to the environmental impacts of bioplastics [2].

Bioplastics are biobased materials, for example, from corn. Bioplastics are biobased, biodegradable, or both [3]. Biodegradation is a chemical process during which microorganisms that are available in the environment convert materials into natural substances such as water, carbon dioxide, and compost (artificial additives are not needed). The process of biodegradation depends on the surrounding environmental conditions (e.g., location or temperature), on the material, and on the application.

The family of bioplastics is divided into three main groups (Figure 1):

1. Biobased or partly biobased, nonbiodegradable plastics such as biobased polyethylene (PE), polypropylene (PP), poly (vinyl siloxane) (PVS), or poly (ethylene terephthalate) (PET)-so-called drop-ins-and biobased technical performance polymers such as poly (trimethylene terephthalate) (PTT) or thermoplastic polyester elastomers (TPC-ET). 
2. Plastics that are both biobased and biodegradable, such as poly (lactic acid) (PLA) and polyhydroxyalkanoates (PHA) or starch polymers.

3. Plastics that are based on fossil resources and are biodegradable, such as poly (butylene adipate terephthalate) (PBAT), poly (butylene succinate) (PBS), or polycaprolactone (PCL).

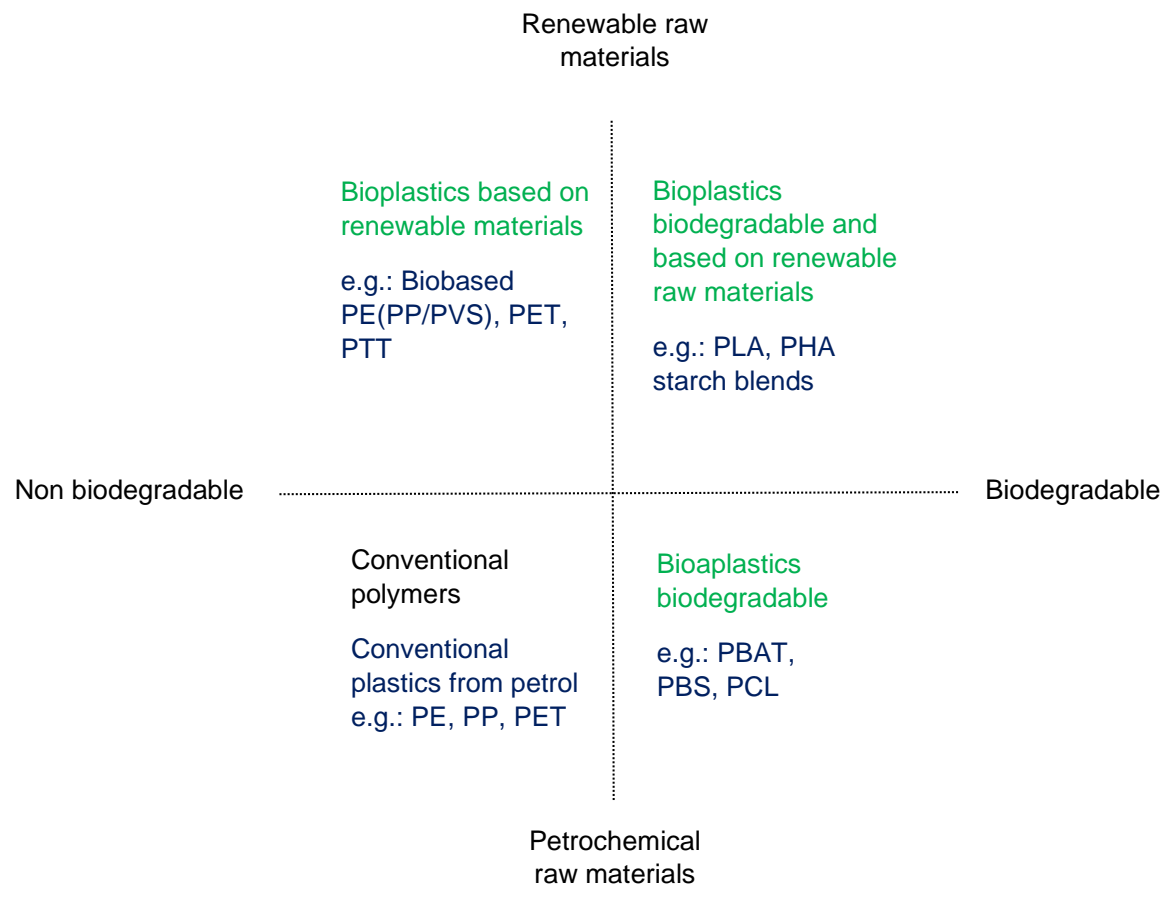

Figure 1. Bioplastics classification. Adapted from [3]. PE: polyethylene; PP: polypropylene; PVS: poly(vinyl succinate); PET: poly(ethylene terephthalate); PTT: poly(trimethylene terephthalate); PLA: poly(lactic acid); PHA: polyhydroxyalkanoates; PBAT: poly(butylene adipate terephthalate); PBS: poly(butylene succinate); PCL: polycaprolactone.

PLA, PHA, and starch blends are biodegradable and biobased materials available on the market [2]. PHA is a biodegradable, biocompatible polymer synthesized by a variety of bacteria as intracellular granules that serve as a form of energy storage [4]. The production of PHA occurs during stress conditions such as depletion of nutrient contents such as nitrogen, sulfur, phosphorous, and oxygen and excess of carbon in the medium [5]. The common microbes that help in the production of PHA are bacteria such as Bacillus cereus, Bacillus megaterium uyuni S29 and Pseudomonas putida Bet 001 [6]. In addition, fungi, such as Mucor racemosis and Saccharomyces cerevisiae [7], and some algae, such as Chlamydomonas reinhardtii and Spirulina platensis [8] can also be used for PHA production. According to research journals, Pseudomonas sps., yeast isolate 1/yeast sps., and Calothrix scytonemicola are considered to be the best microorganisms that can produce a high rate of PHA [9-12].

Poly(lactic acid) (PLA) is one of the most commercially successful bioplastics (at least among the rigid ones) due to its good processability and mechanical properties. Its monomer, lactic acid, is derived from renewable sources, such as starch or sugar, through fermentation. Depending on the particular microbe, the lactic acid fermentation process can produce rather pure D-lactic acid or L-lactic acid with high optical purity or a mixture of them with low optical purity. Many microbes can produce lactic acid, but a competitive commercial process requires a robust, fast-growing, low- $\mathrm{pH}$, and high yield strain with low-cost nutrient requirements. Typical Lactobacillus fermentation is anaerobic, requiring minimal energy for operation, with the most significant cost typically coming from medium components such as carbohydrate. After fermentation, lactic acid must be recovered from the broth and 
purified to meet its final specifications [13]. Most PLA production processes utilize the more efficient conversion of lactide (the cyclic dimer of lactic acid) to PLA via the ring-opening polymerization (ROP) catalyzed by organometal catalysts [14].

Native starches exhibit some limitations mostly related to mechanical integrity, thermal stability, and humidity absorption $[15,16]$. Because of these limitations, starches are often blended with other materials to enhance their properties. Blending starches aims to reduce the production cost, to improve barrier properties and dimensional stability, to decrease the hydrophilic character of starch, and increase its biodegradability [17]. In order to optimize the overall properties of such blends, starches are blended with low molecular mass plasticizers such as glycerol, glucose, sorbitol, urea, and ethylene glycol [18]. The addition of plasticizers conduct to thermoplastic starch (TPS) [19], which is characterized by the spontaneous destructuration of the semicrystalline structure of starch and the formation of hydrogen bonds between the plasticizer and the starch [20]. Depending on the type of the plasticizer blended with the starch, the final properties of the TPS differ. In general, plasticizers produce an increase in flexibility, extensibility, and fluidity by reducing the strong intermolecular chain interactions. Additionally, TPS remains a very hydrophilic material. Recent advances in starch blending include blending TPS with biodegradable polymers is one of the most recent advancements mainly in food packaging applications [21].

Extensive evaluations of the degradation of these materials have been conducted to address environmental problems such as pollution, accumulation in landfills, and aggregation of persistent organic pollutants. Degradation is a process by which polymers are fragmented into smaller molecules or elements. Note that not all bioplastics are biodegradable. The presence of hydroxyl group makes bioplastics hydrophilic, which expedites the reaction kinetics for hydrolysis by absorbing water. The degradation process of bioplastics depends on the origin of the polymer and its chemical/physical properties (e.g., chemical structure, surface area, crystallinity, hydrophobicity/hydrophilicity, molecular weight). Life cycle analysis (LCA) can be used to determine the environmental impacts of a material and/or its production process throughout its production, distribution, use, and disposal [22]. Figure 2 shows a list of the most affecting factors to biodegradability.

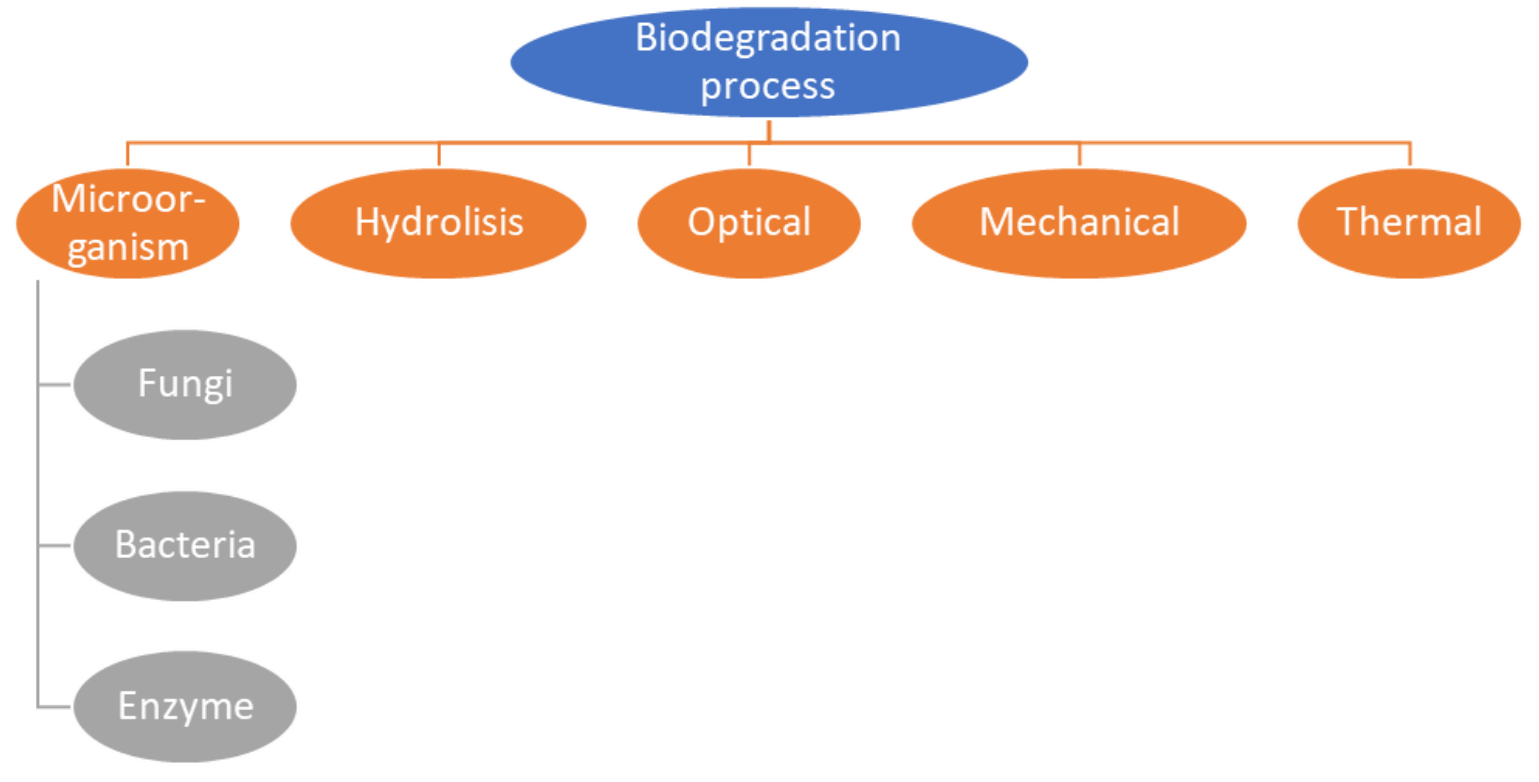

Figure 2. List of the major factors influencing the natural degradation of a polymer. Adapted from [22].

These materials are plastics obtained from renewable sources and/or degrade naturally, some of them in a few years. Moreover, they can be obtained from different resources; most of them are wastes, so this industry is considered to contribute to circular economy. To build our economy on a sustainable basis, we need to find a replacement for fossil carbon 
as chemical industry feedstock [23]. Bioplastics, derived from biobased polymers, may provide a solution. Unlike the chemically synthesized polymers, biobased polymers are derived partially or completely from biomass (plants). Biomass used for bioplastics stems from e.g., corn, sugarcane, or cellulose. Some microorganisms are particularly capable in converting biomass into bioplastics while employing a set of catalytic enzymes [2,24].

The emerging biobased plastics market is still small compared to traditional biobased polymers and biomaterials. The global capacity of the emerging biobased plastics was only 0.36 million tons in 2007. However, the market grew strongly between 2003 and 2007 (approximately 40\% per year). The technical substitution potential of biobased plastics replacing petrochemical plastics is estimated at $90 \%$, demonstrating the enormous potential of biobased plastics [3]. Global capacity of biobased plastics is expected to reach 3.45 million metric tons in 2020 [1]. In the future, global bioplastics production capacity is set to increase from around 2.11 million tons in 2019 to approximately 2.43 million tons in 2024. Biodegradable plastics, all together, including PLA, PHA, starch blends and others, account for over 55.5 percent (over 1 million tons) of the global bioplastics production capacities. The production of biodegradable plastics is expected to increase to 1.33 million in 2024, especially due to PHA significant growth rates [25].

The framework for action on climate and energy until 2030, adopted by the European Council in October 2014, contemplates a series of political goals and objectives for the entire EU during the period 2021-2030. Key targets for 2030 are at least $40 \%$ reduction in greenhouse gas emissions (compared to 1990), at least 32\% renewable energy share, and at least $32.5 \%$ improvement in energy efficiency [26]. Working on this frame, there is an increasing interest to be less dependent from oil, including all its byproducts, such as plastics.

The Organisation for Economic Co-operation and Development (OECD) [27] is reporting about a new concept, the biobased economy (bioeconomy). It first emerged as a policy concept within the OECD at the start of the 21st century. It linked advances in biotechnology to innovation and "green growth" via the use of renewable biological resources and innovative bioprocesses in industrial scale biotechnologies, firstly to produce sustainable products, jobs and income [28], and secondly to address global challenges such as climate change. In 2009, the OECD stated that the bioeconomy "can be thought of as a world where biotechnology contributes to a significant share of economic output" [29], and the OECD publication Towards Green Growth provided recommendations to help governments identify policies with the potential to achieve the most efficient shift to greener growth [30]. Bioplastics are becoming a crucial component in the drive to create a fully sustainable and circular bioeconomy. The EU has been actively supporting the development of these materials through ambitious and collaborative research that aims for a greater uptake that will help transform Europe plastics industry over the coming years [31].

Bioeconomy strategy is part of the Europe 2020 Flagship Initiatives Innovation Union and A Resource Efficient Europe [32]. The Resource-efficient Europe Flagship [33] is part of the Europe 2020 Strategy, and it supports the shift toward sustainable growth via a resource-efficient, low-carbon economy.

The Roadmap to a Resource Efficient Europe is one of the main building blocks of the resource efficiency flagship initiative. The roadmap sets out a framework for the design and implementation of future actions. It also outlines the structural and technological changes needed by 2050, including milestones to be reached by 2020 . The roadmap recommends an integrated approach across many policy areas, and the instruments employed are to include: legislation, market-based instruments, refocusing of funding instruments and promotion of sustainable production and consumption [34].

Today, bioplastics are an alternative for different sectors, such as packaging, beverages, water, insulation materials, and many more [35]. Over a third of consumption is in packaging applications (with common products including containers and plastic bags) and another third or more in building products including common products such as plastic pipes or vinyl cladding. In developing countries, usage patterns may differs lightly; for instance, in India, 42 percent of resin consumption was reported to be in the packaging 
sector [36]. Automotive applications and toy/furniture manufacturing use smaller but significant volumes of plastics. Use of plastics in the developing world is increasing as the lower unit cost and improvements in performance specifications continually promote its substitution for materials such as paper, metals, wood, and glass [25].

The aim of this paper is to evaluate how bioplastics are studied worldwide, finding if there is a penetration of this concept in the research of countries all over the world, and finding a connection between economic needs and governmental policies.

\section{Methodology and Data Sources}

Wuni [37] stated that WoS and Scopus databases can be used to extract bibliometric data, but the content in the same search or query tend to differ. Moreover, Cabeza et al. [38] showed that Scopus contains more publications in the area of technology. Therefore, this paper uses Scopus for the bibliometric study.

The query used in this study included the string with the key message of the paper: "bioplastic".

Then, all references were downloaded from Scopus, as well as the statistics for the bibliometric analysis. Finally, the software VOSviewer [39] was used to analyze relations between countries and keywords.

The study was done with different geographic coverage. First, all publications worldwide were considered. Then, all countries from EU were considered together to compare this territory to others, such as the USA or China. After sorting first 10 countries investigating bioplastics, several countries from Europe were also considered individually (Germany, Spain, and Italy). In Asia: China, India, Thailand, Malaysia, and Japan were assessed. The selection of countries was carried out to have representation from developed and developing countries, checking the 10 countries with more documents published.

The world population was obtained from United Nations, Department of Economic and Social Affairs [40], and the number of researchers from United Nations Science Report [41]. The Gross Domestic Product (GDP) was obtained from the International Monetary Fund.

The bioplastics policies from all the governments of selected countries have been studied from several sources.

\section{National Policies on Bioplastics and Bioeconomy}

We analyze the bioeconomical governmental policies of the 10 countries with more bioplastic related publications, as analyzed in Figure 4. We include Canada, as it is the 11th country in terms of bioplastic publications.

\subsection{China}

In China, political interest in the bioeconomy relates strongly to the promotion of biotechnology development. Appropriate policies have already been promoted since the 1980s and have made a major contribution to helping China become one of the leading biotechnology players worldwide [42].

China environmental policy has been updated in the last twenty years. China has formulated new environmental laws, which include the Cleaner Production Promotion Law (in 2002) [43], the Environmental Information Disclosure Decree (in 2008) [44], the Law on Promoting Circular Economy (in 2009), and the new environmental policy instruments such as voluntary agreements and emission trading. All those laws show that China policy follows OECD laws. The 16th Congress of the Communist party in China (2002) [45] created a sustainable development plan. In this congress, China adopted circular economy ideas, developing laws to several sustainable initiatives started in previous decades. China adopted the circular economy due to the environmental damage and resource depletion that was occurring from going through its industrialization process. Biotechnology development was a prominent topic in the 11th and the 12th Five-Year Plan for Economic and Social Development (FYP) and the related subplans [46]. 
In January 2006, China initiated a 15-year Medium- to Long-Term Plan (MLP) for the Development of Science and Technology. The MLP calls for China to become an "innovationoriented society" by the year 2020 and a world leader in science and technology (S\&T) by 2050 . According to the MLP, China will invest $2.5 \%$ of its increasing gross domestic product in R\&D by 2020, up from $1.34 \%$ in 2005; raise the contributions to economic growth from technological advance to more than $60 \%$; and limit its dependence on imported technology to no more than $30 \%$. The plan also calls for China to become one of the top five countries in the world in the number of invention patents granted to Chinese citizens, and for Chinese-authored scientific papers to become among the world's most cited [47]. As expected that the MLP would have an impact on the trajectory of Chinese development, China's growth started after the creation of this plan.

\subsection{United States}

To reduce nation reliance on petroleum, the United States Department of Agriculture (USDA) BioPreferred program was created by the Farm Security and Rural Investment Act of 2002 (FSRIA) and reauthorized by the Food, Conservation, and Energy Act of 2008 (frequently referred to as the 2008 Farm Bill) to increase the purchase and use of biobased products and spur economic development, increasing the use of renewable resources [48]. Later in 2012, Obama administration announced The National Bioeconomy Blueprint [49], aimed at fostering all biology-based businesses, including pharmaceuticals and medical devices. Growth in documents published started in 2004, two years after the BioPreferred program, and it continued with the different policies implemented.

\subsection{Germany}

In 2006, the German Ministry of Education and Research created the Clusters BioIndustrie 2021 competition, with a budget of 60 million. The aim was the formation of strategic clusters, which were supposed to bundle competencies of companies, academies, and actors in the financial sector within a certain subject area of industrial biotechnology. In 2009, Germany established the Bioeconomy Research and Technology Council, which is the BMBF (German Ministry of Education and Research) in conjunction with the BMELV (German Ministry of Food, Agriculture, and Consumer Protection). It is an independent advisory board to the government for all matters regarding the bioeconomy. It consists of experts from academia, private sector research, and federal government departmental research. The role of the bioeconomy council is to contribute to enabling a leading position for Germany in the future, and it has published a number of recommendations [50,51] for actions and the national strategy, itself, is based on its recommendations. The German strategy entitled National Research Strategy Bioeconomy 2030: Our Route towards a Biobased Economy [52] was published in 2011, before the official EU strategy. One of the focuses is to skip limits in fossil and mineral supplies means, searching for renewable raw materials for industrial and material-energy use, such as bioplastics. Figure 5 shows that Germany growth starts in 2010, six years after first cluster proposal, and it continued in 2016, five years after the National Research Strategy Bioeconomy 2030 publication.

\subsection{Japan}

After the ratification by the Japanese Government of the Kyoto Protocol in June 2002, the Government announced (December 2002) two measures: the Biotechnology Strategic Scheme and the Biomass Nippon Strategy [53]. The main objective of the two measures was to promote the utilization of biomass and to reduce the consumption of fossil resources and to mitigate global warming through the use of biotechnology. The policy objective stated in the Biotechnology Strategic Scheme was to replace approximately 20\% (2.5 to 3 million tons per year) of conventional plastics (based on petrochemical raw material) with plastics from renewable resources by 2020. The Biomass Nippon Strategy was revised in March 2006 to accelerate the growth of biomass towns and to promote the utilization of biofuels. 
The Biomass Nippon Strategy has prompted companies such as Toyota and NEC (Nippon Denki Kabushiki-gaisha) to accelerate their levels of research and development into biobased plastics and to raise the biobased content of their products. Japanese vehicle manufacturer Toyota is planning to switch $20 \%$ of the plastics used in its vehicles to biosourced plastics by 2015 and expects bioplastics to help in its efforts to accomplish its company-wide goal of reductions in CO2 emissions [54]. To help to develop the market for bioplastics, the Japan BioPlastics Association (JBPA) started a certification program for products containing biomass-based plastic content. The association has established standards as well as a methodology for the analysis and the evaluation of these plastics. The program includes a logo easily recognizable by consumers. The JBPA certification, called BiomassPla, specifies that products with the logo must contain $25 \%$ biobased plastic by weight. So far, JBPA has certified about 900 biodegradable plastic products in Japan. The system is based on a positive list system for all components, biodegradability specifications based in Japanese Industrial Standards, safety certification of all components and proof of no hazardous effects to soil [55].

Every five years, a new Science and Technology Basic Plan is drawn up in Japan to support the promotion of science and technology. The 4th Science and Technology Basic Plan (2011-2015) set out the current priorities. At a budgetary level, it set a target of $4 \%$ of GDP dedicated toward expenditure on research and development by 2020 . Of this, 3\% was to be by industry and $1 \%$ by government. The total government expenditure over the duration of the plan was to be around EUR 240 billion, assuming nominal growth of $2.8 \%$. The 4th plan positioned green innovation for environment and energy as one of the two major pillars of growth (the second being life innovation, to effect milestone advances in medicine, health and caregiving). The government would promote green innovation with the aim of addressing climate change issues that Japan and the world are facing and would realize the world's most advanced low-carbon society through the Council for Science and Technology Policy [56]. Japanese growth started in 2011, five years after first revision of the Biomass Nippon Strategy.

\subsection{Spain}

There are several organisms to promote bioplastics in Spain. The Spanish Technological Biomass Platform (BIOPLAT) was launched in 2007 with support from the former Ministry of Science and Innovation and the Ministry of Economy and Competitiveness. Its objective is to provide a framework in which all sectors involved in biomass can work together and in a coordinated way to achieve the successful commercial establishment of biomass-related initiatives in Spain, with steady and continuous growth in a competitive, sustainable and properly regulated manner.

The Spanish Sustainability Observatory (OSE) is an independent organization created in 2005 in collaboration with the Ministry of Agriculture, Food and Environment; the Biodiversity Foundation; and the General Foundation of the University of Alcalá. It has many indicators regarding socioeconomic and development, ecoefficiency and development of agriculture and fishing, industrial sector, and homes [57].

The Platform of Biotechnological Markets is a biotechnology platform set up by ASEBIO (The Spanish Association of Bio-Companies), with support from the former Ministry of Science and Innovation and the Ministry of Economy and Competitiveness. It was launched in 2010 with the objective of setting up stable, efficient, and multilateral communication channels between the different stakeholders of the science-technology-company system to foster biotechnology innovation, technology transfer, and translation to society. The sciencetechnology-company system has innovating elements for financing, defining, and solving regulatory issues to turn them into a real opportunity for the biotechnology business sector.

In April 2015, the Ministry launched the National Food and Agriculture and Forestry Innovation and Research Program. Public funding comes from the Spanish government and from the EU Horizon 2020 research program. The budget is around EUR 200 million a year, and just less than EUR 1.1 billion is earmarked for the strategy by 2020. The program is 
being used as a monitoring body to ensure the implementation of the strategy, a Spanish Bioeconomy Observatory [58]. As seen in Figure 5, growth in Spain started in 2011, four years after the BIOPLAT initiative.

\subsection{India}

The Department of Biotechnology (DBT), Government of India, announced the First National Biotechnology Development Strategy in September 2007. The implementation of Biotech Strategy 2007 provided an insight into the enormous opportunities. It was felt opportune to take a critical look at the Indian biotech sector, as it will likely unfold over the next $5-6$ years.

In year 2015, DBT announced The National Biotechnology Development Strategy-2015-2020, which was framed after a wider consultation with stakeholders. It would seamlessly build on the earlier Strategy to accelerate the pace of growth of biotechnology sector at par with global requirements [59].

The Major initiatives of the National Biotechnology Development Strategy 2015-2020 are:

- To launch four major missions in healthcare, food and nutrition, clean energy, and education.

- To create a technology development and translation network across India with global partnership, including 5 new clusters, 40 biotech incubators, 150 Technology Transfer Offices (TTOs), and 20 bioconnect centers.

- To ensure strategic and focused investment in building the human capital by setting up a Life Sciences and Biotechnology Education Council.

The National Biotechnology Development Strategy works around value-added biomass and products from natural resources, developing biomaterials and bioplastics among others [60]. Growth in India started in 2016 and continued in 2018, just after this National Strategy in 2015.

\subsection{Malaysia}

Since the 1990s, Malaysia aspired to make biotechnology and bioeconomy as its engines of economic growth to use the abundance of natural resources and biodiversity. The public sector plays an integral role in developing the sector, and various incentives are in place for the private sector to be actively involved and to forge collaboration with the public sector. The country launched its National Biotechnology Policy in 2005 and later launched its National Bioeconomy Programme (NBP) [61] in 2010 to become the first country in South East Asia and second in Asia after China to have such an initiative [62]. The main aim of NBP is to develop biotechnology sector into one of the key economic drivers for the nation, contributing $5 \%$ of the nation GDP by 2020 .

The Bioeconomy Transformation Program (BTP) is in line with the government objective to develop Malaysia into a high-income nation by the year 2020. The BTP aims to achieve this by focusing on biobased industries in Malaysia, a sector that has been identified as having enormous potential to further develop the nation due to the abundance of natural resources available, through effective execution strategies from the government and BiotechCorp [63]. In Figure 5, we can see Malaysia increases the documents in 2012, two years after the National plan, but it is in 2018 when it reaches the maximum documents per year.

\subsection{Italy}

Networks in the Italian bioplastics industry are dense and highly inclusive although composed mainly of firms [64]. The only Italian governmental policy regarding bioplastics is banning the distribution of traditional plastic carrier bags, allowing only the commercialization of biodegradable single-use and long-life reusable bags, according to DL152/2006, Financial Law 2007, and New law 28, 24/3/2012.

In May 2012, the Italian Ministry of Education, Universities and Research launched a call for implementing clusters focused on top innovative sectors for the country, one of 
them being green chemistry. The cluster, The Italian Technology Cluster of "Green Chemistry" (SPRING), Sustainable Processes and Resources for Innovation and National Growth, currently has 117 members (public and private), including the Italian Federation of Chemical Industries. It has about EUR 50 million of public and private funds addressing the finance of parallel; complementary three-year R\&D projects; and training projects for masters students, $\mathrm{PhD}$ students, and young scientists in the area of green and sustainable chemistry, biomaterials, and industrial biotechnology. Furthermore, it will have the responsibility to develop the strategic R\&D agenda and the implementation action plan on a biobased economy for Italy. In 2019, SPRING developed and presented to the Italian Ministry of University and Research a triennial Action Plan where four development roadmaps and related practical action [65]. Following this strategy, we can see it was in 2012 when Italy increased the documents published and, in 2017, increased to more than 10 per year.

\subsection{Indonesia}

In Indonesia, bioeconomy development is politically fostered mainly in two areas: bioenergy and agroindustry. With the Grand Strategy of Agricultural Development 2015-2045, the government formulated its first long-term agricultural and rural development plan. The Indonesian Ministry of Agriculture has led the formulation of the Grand Strategy, and the Directorate General of New Renewable Energy and Energy Conservation in the Ministry of Energy and Mineral Resources is responsible for bioenergy development [66].

Bioenergy development is considered important for contributing to Indonesia energy autonomy, to economic growth, ecological sustainability, and improved health in rural areas. The agricultural strategy seeks to ensure food security, mitigate climate change, and conserve valuable national resources while contributing to economic growth and inclusive development. Primary agricultural production is still the largest employer in the country (about 30 percent of the workforce). With a view to a biobased economy, the plan formulates the vision to transition to "a sustainable agricultural bioindustry system to produce diversified healthy foods and high value-added products from tropical agriculture and maritime resources for food sovereignty and farmers' welfare". The foundation for a sustainable agricultural bioindustry should be laid in the period 2013-2015 and further strengthened by 2019 [67]. Published documents growth stared in 2017, two years after the Grand Strategy of Agricultural Development.

\subsection{Thailand}

Thailand is a biomass-rich country with abundant feedstock resources and more than 4.000 companies in the plastics industry. Since 2006, the Thai Government has declared the bioplastics industry to be one of the strategic industries that the government is promoting in its drive toward sustainable growth and development. This resulted in 2008 in the National Roadmap for the Development of Bioplastics Industry, developed by the National Innovation Agency (Ministry of Science and Technology). Strategies covered the entire value chain of the bioplastics industry. The roadmap provided targets, indicators, and action plans and designated sectors and organizations for implementation. The total budget for the roadmap strategies at that time was USD 60 million. It is expected that development of the local bioplastics industry will take place in accordance with the National Roadmap [68]. It was after the National Roadmap that the first document was published, in 2008, and growth started in 2013, with eight publications.

\subsection{Canada}

Canada does not have an overarching bioeconomy strategy, but it has a series of diverse, and often competing, policy visions and frameworks [69]. Both Beyond Moose and Mountains [70], and Plastic's Challenge are initiatives from the Canadian administration to promote the bioeconomy. The Canadian Blueprint: Beyond Moose and Mountains was published in 2008 with the statement, "How we can build the world's leading biobased 
economy". It is not a governmental document, as it is published by BioteCanada, an association representing the biotechnology sector in Canada [69].

In July 2011, a Bioeconomy Committee was formed in British Columbia (BC), Canada. The Committee concluded that there is an urgent need for the government to take a leading role in the further development of British Columbia's bioeconomy [71]. Canada, have large forest areas, which is an important factor for developing a bioeconomy, and they also have research and innovation in the field of biorefining and biobased industries [72].

In 2011, British Columbia (BC) formed a bioeconomy committee under the direction of the Minister of Jobs, Tourism, and Innovation. The role of the committee was to investigate the opportunities for the province in the emerging bioeconomy and also the possibilities for $\mathrm{BC}$ to speed up the growth of the $\mathrm{BE}$ in the province and has, as an outcome, published a bioeconomy strategy for $\mathrm{BC}$ [73]. The committee focuses on the economic value of biological systems. Having significant forest resources, BC views the increased use of biomass for energy and material as opportunities and has also earlier taken an active role in the work to decrease the dependence on fossil resources when, in 2008, a bioenergy strategy for the province was published. Canada's growth started in 2013, two years after the bioeconomy committee, with seven documents published.

\section{Results}

\subsection{Global Bibliometric Analysis}

The query used returned 1346 documents, which were the references used in this paper. The co-occurrence threshold was set at five. The study was performed considering no time limitation; therefore, the results show the publications in this topic until January 2020 (2020 was not included to have full years).

Figure 3 shows that around $70 \%$ publications on the topic are articles, $15 \%$ are conference papers, $10 \%$ are split between reviews and book chapters, and the rest is anecdotic. The same distribution is followed also individually by all countries included in the study, with some exceptions commented upon in the paper.

Figure $3 \mathrm{~b}$ highlights that Indonesia has a big number of publications as conference papers, $75 \%$ of the total. This percentage is much bigger than the rest of countries. The second one is Thailand with $15 \%$ of conference papers; meanwhile, Italy and China have both the lowest ratio, with $2 \%$.

The quantity of publications is an important indicator that reveals development trends of scientific research. The country with more documents published is the USA, followed by Spain. In Figure 4, the first 20 countries are listed.

Figure 5a presents the general trend in number of publications referred to bioplastics. Figure 5a shows that interest on bioplastic started to increase in the year 2000. Since then, the tendency has been exponentially increasing. This growing interest can be linked to fossil dependence concerns and climatic change policies. The biobased economy (bioeconomy) first emerged as a policy concept within the OECD at the beginning of the 21st century. It linked advances in biotechnology to innovation and "green growth" via the use of renewable biological resources and innovative bioprocesses in industrial scale biotechnologies, firstly to produce sustainable products, jobs, and income [28], and secondly to address global challenges such as climate change. 


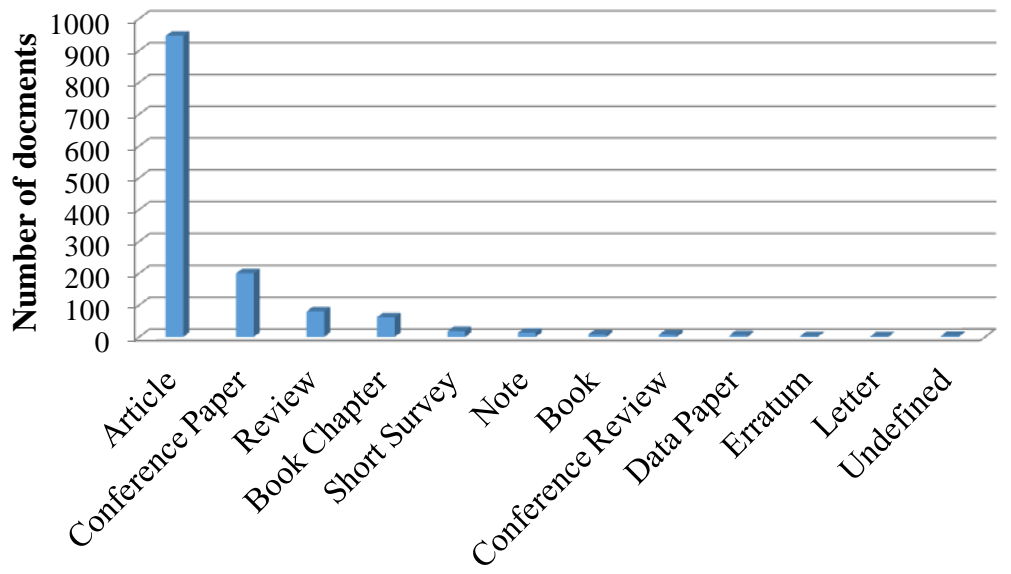

Document type

(a)

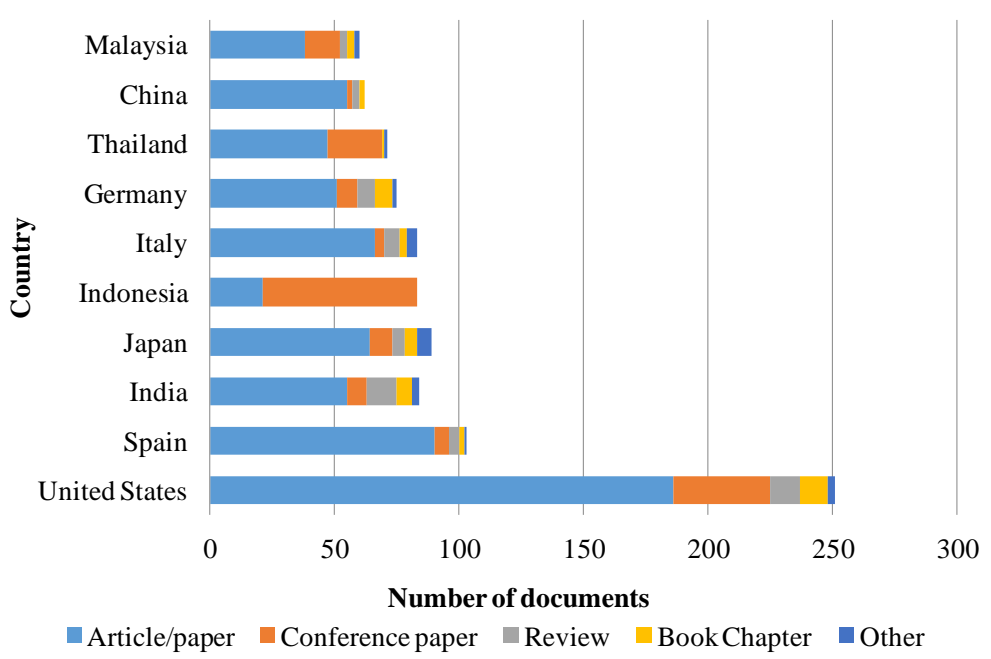

(b)

Figure 3. Document type distribution, (a) global and (b) for the 10 countries with the most publications.

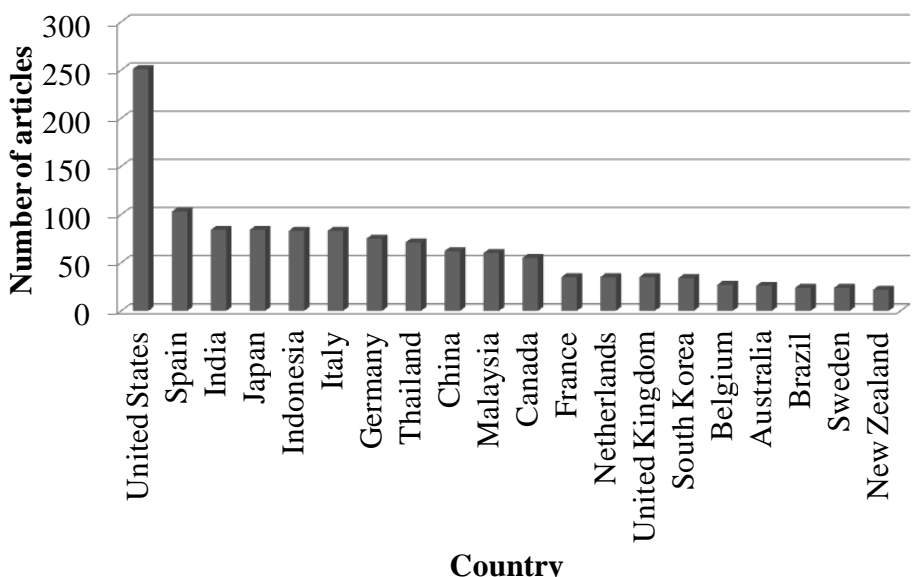

Figure 4. Number of documents per country. 


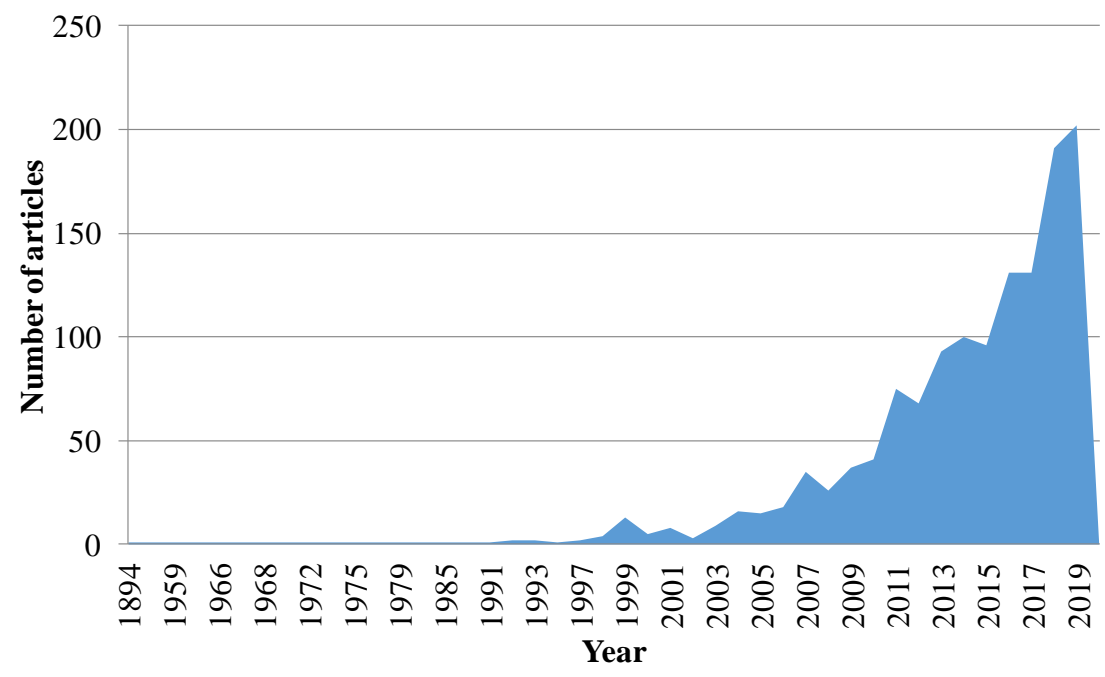

(a)

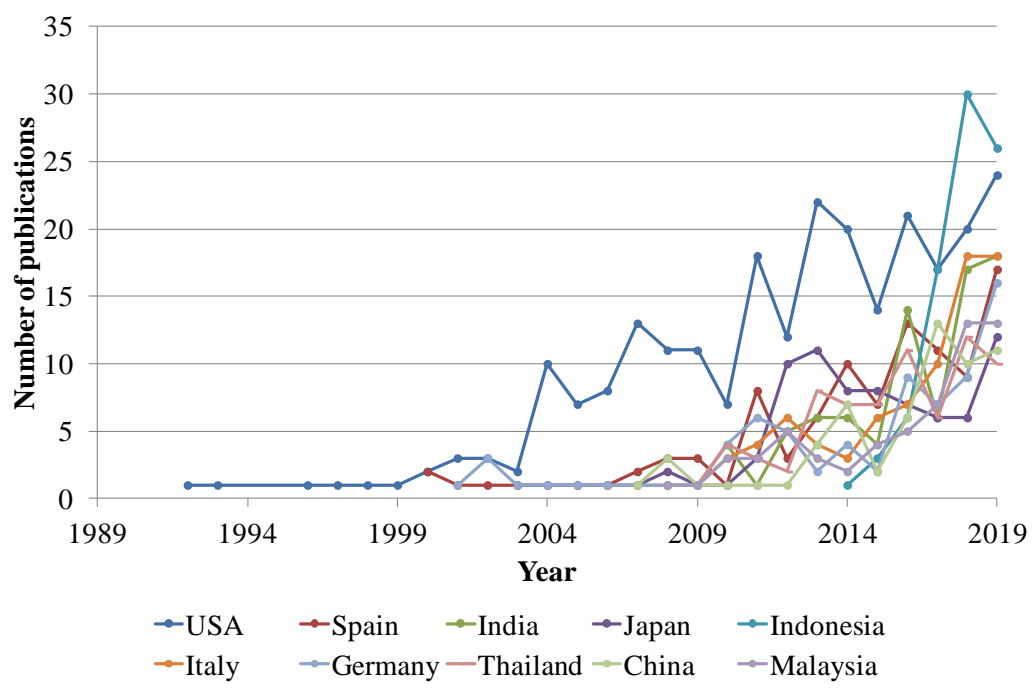

(b)

Figure 5. Trends in number of documents per year, (a) global and (b) for the 10 countries with the most publications.

Figure $5 \mathrm{~b}$ shows that the USA was the first country to publish and also the first to increase the number of publications, followed later by Spain, Germany, and Japan. Since the year 2000, other countries also show an important growth in the number of documents in the topic of study, bioplastics.

Figure 6 shows an analysis of the scientific production related to million inhabitants and thousand researchers. Analyzing the two countries with more publications on the topic, the USA and Spain, the Spanish coefficient is higher when compared with million inhabitants. The Japanese case is interesting, because it has a very high coefficient in terms of researchers but not in publications. Spain is very productive, because it has the higher coefficient related to documents published but not in the number of researchers per million inhabitants. 


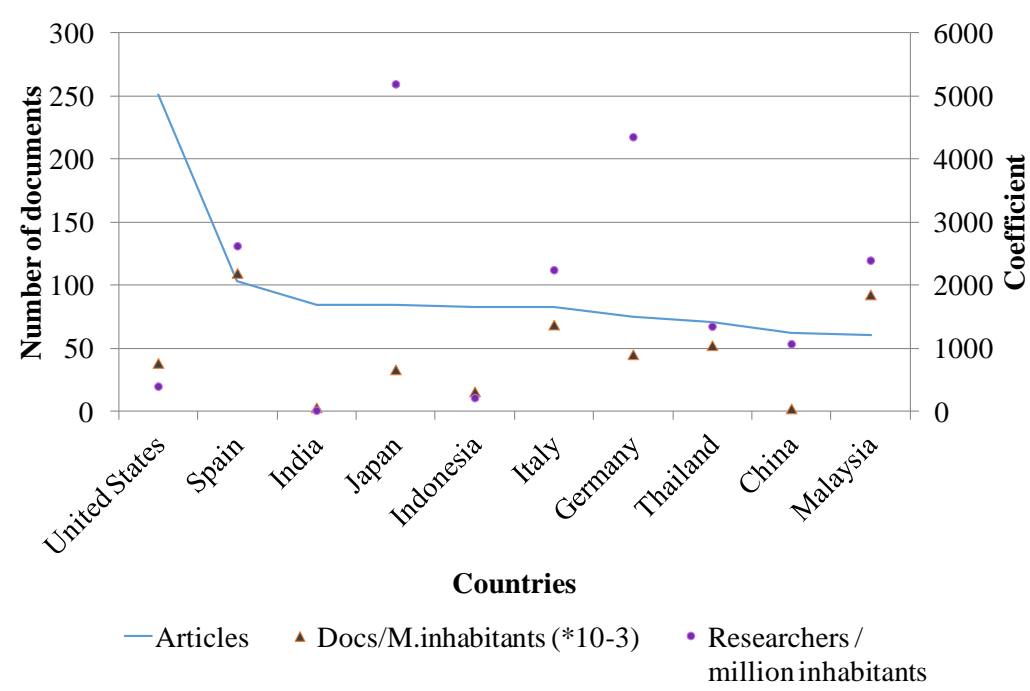

Figure 6. Scientific production per country per million inhabitants and per thousand researchers. Note: docs/ million inhabitants is divided by $1000\left({ }^{*} 10-3\right)$.

Table 1 shows the data of first 10 countries, considering the number of habitants, and a resume of paper density and GDP.

Table 1. Articles density per country.

\begin{tabular}{|c|c|c|c|c|c|c|}
\hline Country & $\begin{array}{c}\text { Million } \\
\text { Inhabitants }\end{array}$ & Articles & $\begin{array}{c}\text { Docs/ } \\
\text { M.Inhabitants }\end{array}$ & GDP 2019, \$ & Art./Th. GDP & $\begin{array}{c}\text { Researchers/ } \\
\text { Million } \\
\text { Inhabitants }\end{array}$ \\
\hline United States & 327.35 & 251 & 0.767 & $56,844.31$ & 4.42 & 398.44 \\
\hline Spain & 46.93 & 103 & 2.195 & $36,311.32$ & 2.84 & 2626.00 \\
\hline India & 1352.62 & 84 & 0.062 & 7314.57 & 11.48 & 15.99 \\
\hline Japan & 126.53 & 84 & 0.664 & $39,763.14$ & 2.11 & 5194.80 \\
\hline Indonesia & 264.16 & 83 & 0.314 & $12,220.82$ & 6.79 & 216.00 \\
\hline Italy & 60.36 & 83 & 1.375 & $35,331.75$ & 2.35 & 2245.00 \\
\hline Germany & 83.02 & 75 & 0.903 & $46,765.48$ & 1.60 & 4355.40 \\
\hline Thailand & 67.79 & 71 & 1.047 & $17,778.84$ & 3.99 & 1350.00 \\
\hline China & 1395.38 & 62 & 0.044 & $17,027.48$ & 3.64 & 1071.10 \\
\hline Malaysia & 32.39 & 60 & 1.853 & $28,705.92$ & 2.09 & 2397.00 \\
\hline
\end{tabular}

The case of Spain is interesting, with the density of articles per million habitants being 2.195, the highest one, followed by Malaysia with 1.853. But when the articles per GDP are analyzed, India has the highest ratio, followed by Indonesia and Thailand. It is those developing countries (Indonesia, Thailand, and India) that have bigger growth in last years.

When analyzing the institutions where the authors of the documents found are associated, 160 different institutions are found to have contributed to this research field. Figure 7 shows the 10 institutions with the most publications on bioplastics. University of Seville from Spain and Michigan State University from the United States are the leaders of this field. These two countries are also the only ones that have more than one center (specifically, two) in the list of top institutions and the two countries with the most publications (Figure 4). 


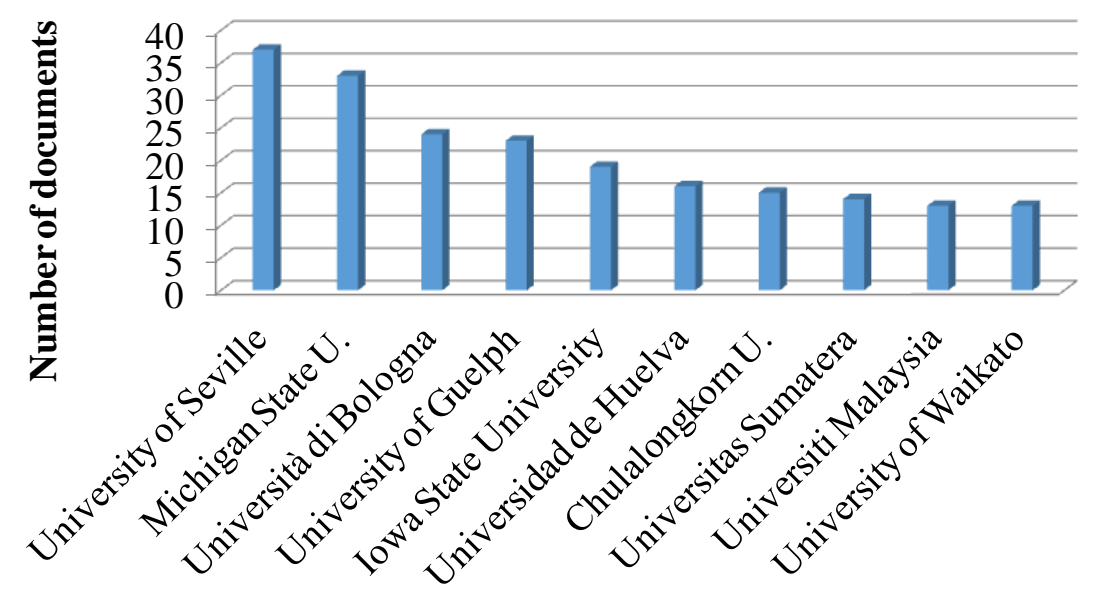

Affiliation

Figure 7. Number of documents for the 10 top institutions.

Figure 8 shows the relationship between countries' publications, obtained with the software VOSviewer. Focusing on individual countries, the United States is the country with the most publications, as seen in Figure 4. It is also one of the first countries that started to publish on the topic of bioplastics (Figure 5), and it does so together with Canada, Belgium, and Netherlands. It is interesting to see that the United States appears in the center of the network, with strong connections with Spain, Italy, and Japan, among others.

In Figure 8a, the countries from the European Union are together compared with the rest of the world. In the center of the network one can see the EU with a very strong connection with the United States. Moreover, connections of the EU with United Kingdom, Brazil, Mexico, Argentina, and Canada can be found. Once all the countries from the EU are accounted for, this territory is the one with the most publications, but the oldest publications are still from the United States and Canada. This figure also shows strong connections between the EU and Japan or Canada. On the other hand, China and India have started more recently to publish research in this field, but, as seen in Figure 5, their contribution is growing very fast. India is the country with the third-most number of publications, and China is the ninth country in the world in terms of bioplastic publications. Additionally interesting are Indonesia and Malaysia. Those countries have just started to publish, but they are already the 5th and 10th in the world in number of documents.

Figure 8c shows the European Union countries co-occurrence map. The network shows Spain in the center, with strong connections with Germany, Italy, France, and Sweden. As seen before, Spain is the country with the most publications, followed by Italy and Germany. These are the only countries from the EU to appear in the top 10 list (Figure 4). But it is interesting to see that Belgium, Netherlands, and France were the first to investigate on this topic and to see some of the newest members, including Romania, Slovenia, and Estonia, to appear, though with only a few contributions. Greece has only one publication so far.

The analysis of authors with more contributions in this area (Table 2) shows that M. Misra from the University of Guelph, Canada, is the author with the most publications. A colleague from same university, A.K Mohanty, is listed as the second one. As Canada is the 11th country in number of documents, these two authors have very big relevance in this field in their country: they have published $5 \%$ of all documents related to bioplastics. M. Misra has published 516 documents, 468 of which were co-authored with A.K. Mohanty. From these 468 documents, 316 are articles and 112 conference papers. They mainly investigate in material science (349), chemical engineering (177), chemistry (175), and engineering (126). The most cited documents from M. Misra and A.K. Mohanty are "Sustainable BioComposites from Renewable Resources" [74] (1474 citations) and "Perspective on Polylactic Acid (PLA) based sustainable Materials for durable applications" [75] (260 citations). 


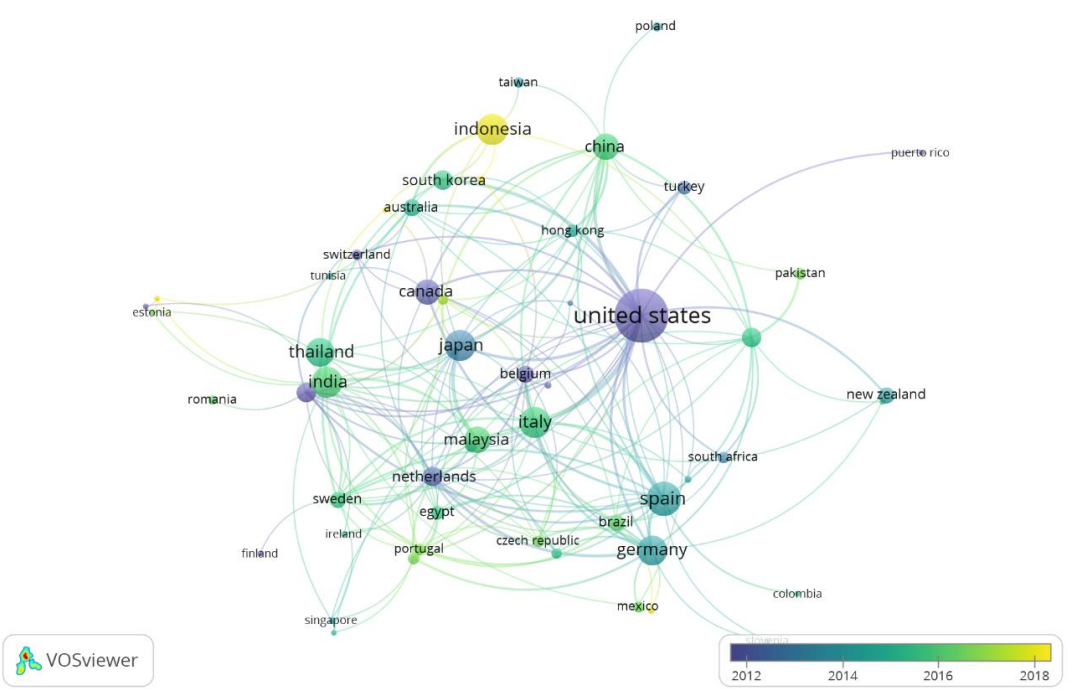

(a)

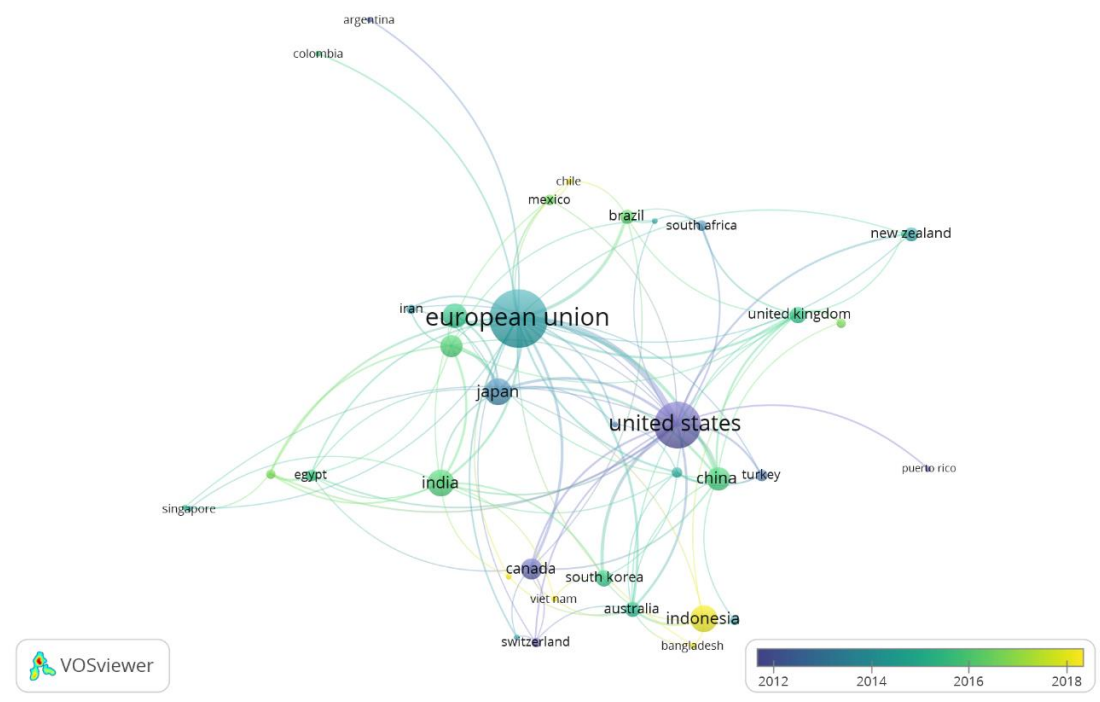

(b)

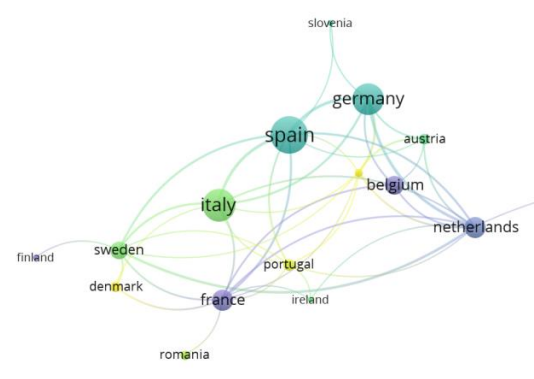

\& vosviewer

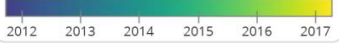

(c)

Figure 8. Countries' relationships (a) considering worldwide connections; (b) EU as territory; and (c) only countries from EU. 
Table 2. Authors with more publications in the bioplastics field.

\begin{tabular}{cccc}
\hline Author Name & Number & Country & Institution \\
\hline Misra, M. & 39 & Canada & University of Guelph \\
\hline Mohanty, A.K. & 33 & Canada & University of Guelph \\
\hline Guerrero, A. & 30 & Spain & University of Seville \\
\hline Accinelli, C. & 18 & Italy & Università di Bologna \\
\hline Romero, A. & 18 & Spain & University of Seville \\
\hline Bengoechea, C. & 16 & Spain & University of Seville \\
\hline Drzal, L.T. & 16 & United States & Michigan State University \\
\hline Grewell, D. & 14 & United States & North Dakota State University \\
\hline Partal, P. & 14 & Spain & University of Huelva \\
\hline Martínez, I. & 13 & Spain & University of Huelva \\
\hline
\end{tabular}

The institution with the second-most documents is University of Seville (Spain), with A. Guerrero with 30 publications. He has published 148 documents, 73 of them with A. Romero, and 39 with C. Bengoechea. The most cited articles written by these three authors are "Rheology and processing of gluten based bioplastics" [76], with 69 citations, and "Egg white-based bioplastics developed by thermomechanical processing" [77], with 66 citations.

C. Accinelli, from the University of Bologna (Italy), has published 18 bioplastic documents, with a total of 98 co-authored documents, 19 with A. Vicari, 15 with H. K. Abbas, and 13 with W. T. Shier. The most cited article is "Deterioration of bioplastic carrier bags" [78], and the second one is "Removal of oseltamivir (Tamiflu) and other selected pharmaceuticals from wastewater using a granular bioplastic formulation entrapping propagules of Phanerochaete chrysosporium" [79].

The main author from University of Huelva (Spain) is P. Partal, who has published 114 documents, 17 of which are co-authored with I. Martínez. P. Partal's main co-author partner is C. Gallegos, with affiliations at University of Seville, University of Huelva, and currently Fresenius Kabi AG from Hessen Germany.

Figure 9 presents the co-authorship map showing different clusters without connections; each cluster is mainly formed by authors from the same country. There are no investigations carried out by different universities together, except in Spain. The University of Huelva and the University of Seville, and Mr. L.T. Drzal, from Michigan State University, have connections with University of Guelph, as they are grouped together (Figure 10).

Figure 11 analyzes where the authors published the documents found. Journals on the topic of polymers are in the first and the third position. Journal of Applied Polymer Science is the first source title, with 39 publications. The most cited article (187 times) is "Influence of Glycerol and Water Content on the Structure and Properties of extruded starch plastic sheets during aging" [80]. Journal of Polymers and the Environment is the third source, with 28 documents. The most cited publication in this journal is "Sustainable Bio-Composites from renewable resources: Opportunities and challenges in the green materials world" [74].

In second and fourth place, proceedings of conferences such as IOP Conference Series: Materials Science (33 documents) and Engineering and AIP Conference Proceedings (23 documents) are found. The most cited article from IOP Conference Series: Materials Science (9 citations) is "Water absorption and its effect on the tensile properties of tapioca starch/polyvinyl alcohol bioplastics" [81]. The most cited from AIP Conference Proceedings is "Thermal and mechanical properties of bioplastic poly(lactic acid) compounded with silicone rubber and talc" (4 citations) [82]. 


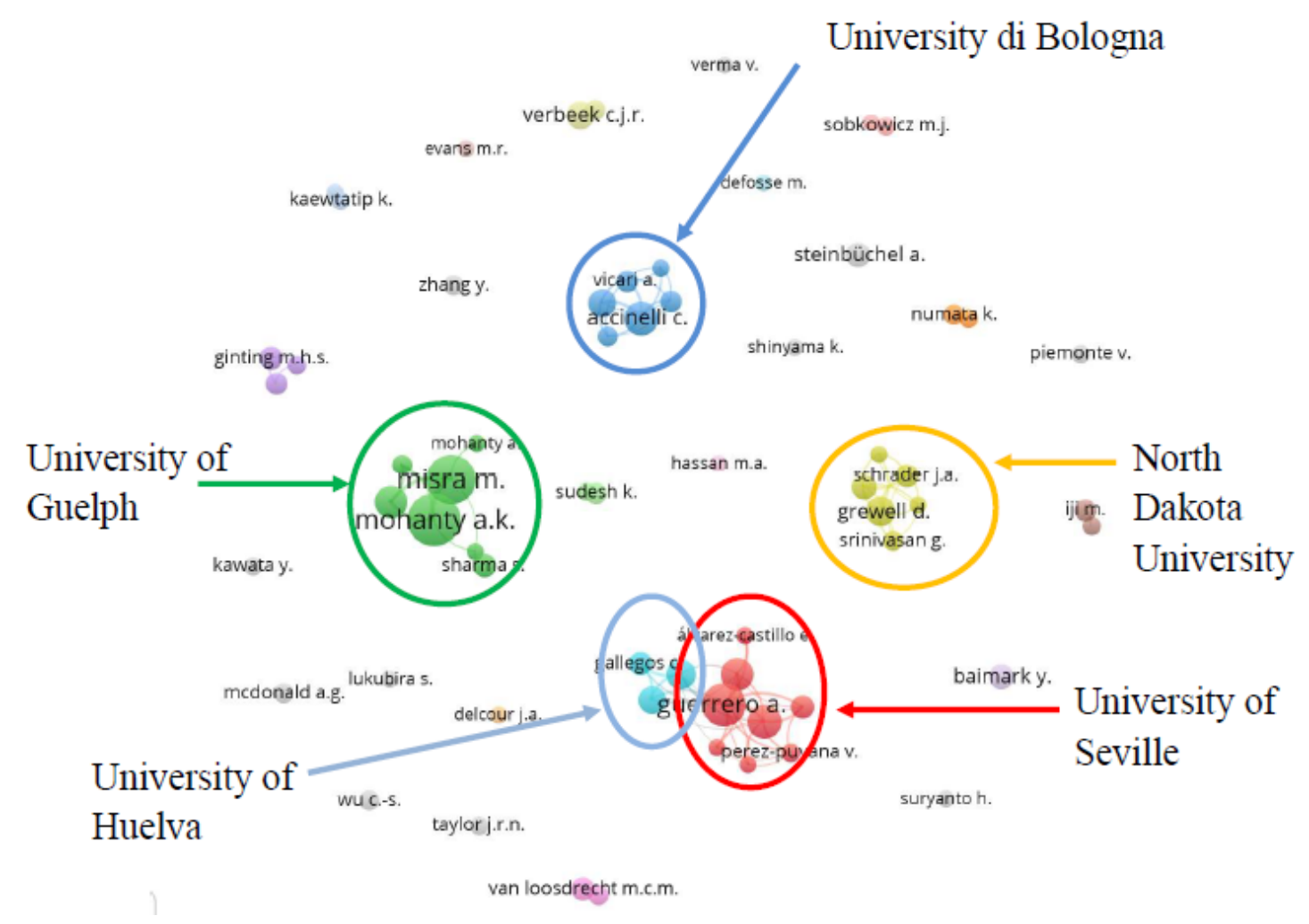

Figure 9. Co-authorship map.

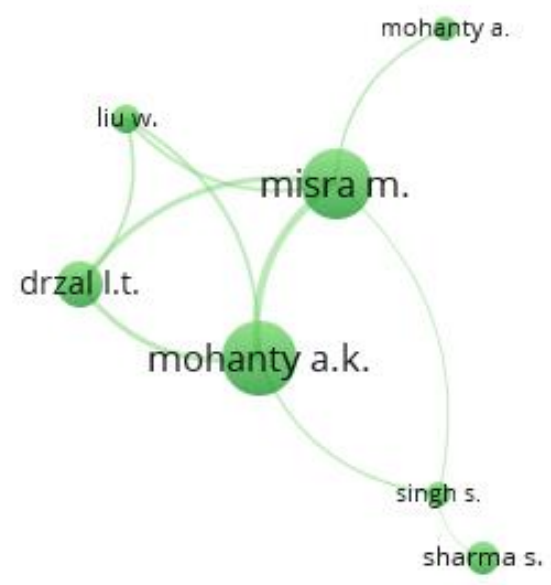

Figure 10. Co-authorship map for University of Guelph and Michigan State. 


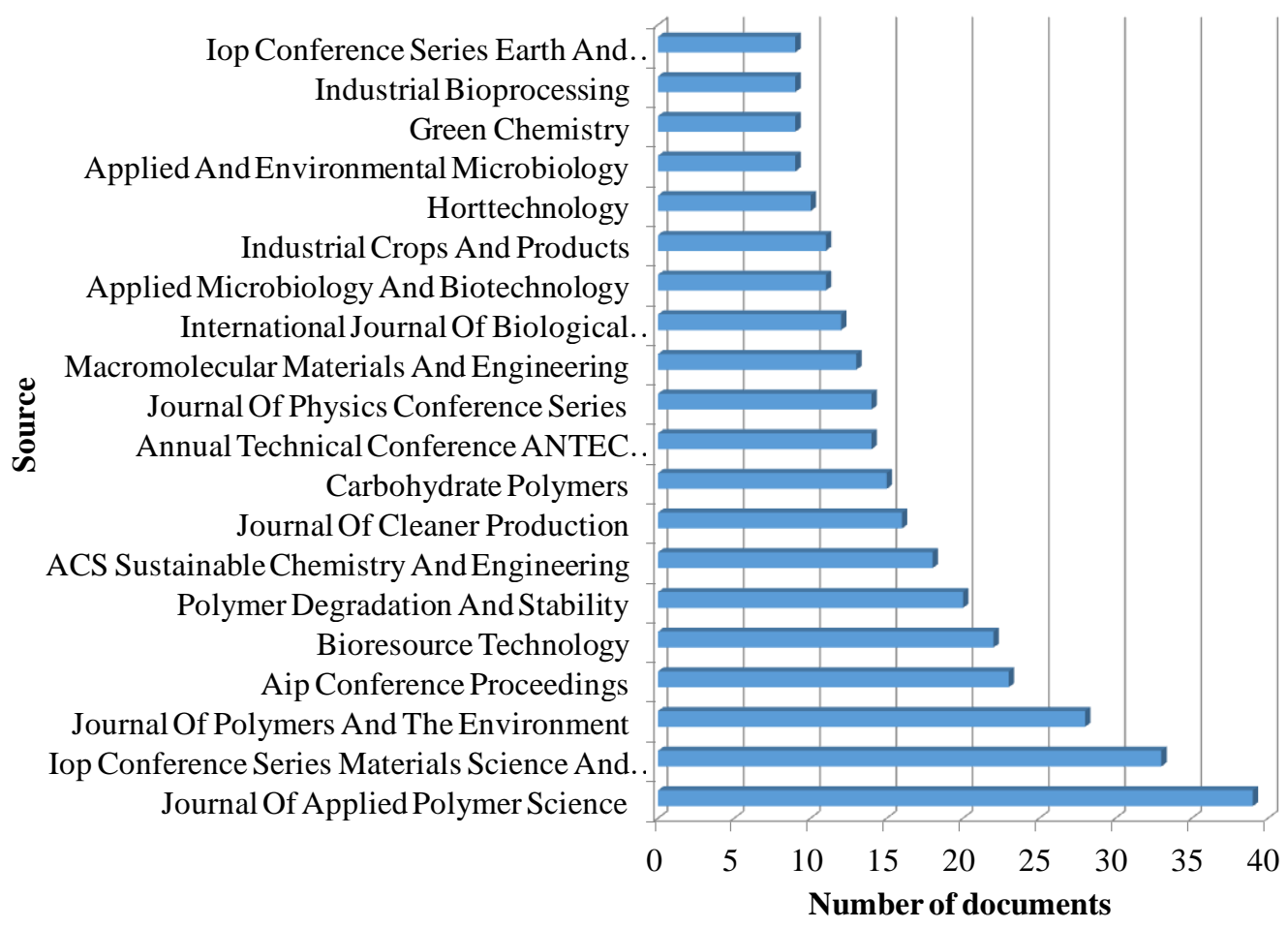

Figure 11. Source and journals for bioplastic publications.

\subsection{Keywords Analysis}

Figure 12 is the co-occurrence map of the query of worldwide publications. The bibliometric analysis shows that there were 849 items involved in this research. One of the first items to highlight is the difference between bioplastic and plastic and all the terms related to manufacturing, characterizing assessment, etc., of both materials. The co-occurrence was set at five, and the co-keyword network clearly illustrated six distinct clusters. Appropriate labels of the six main clusters could be allocated to each of them by analyzing their main node circles.

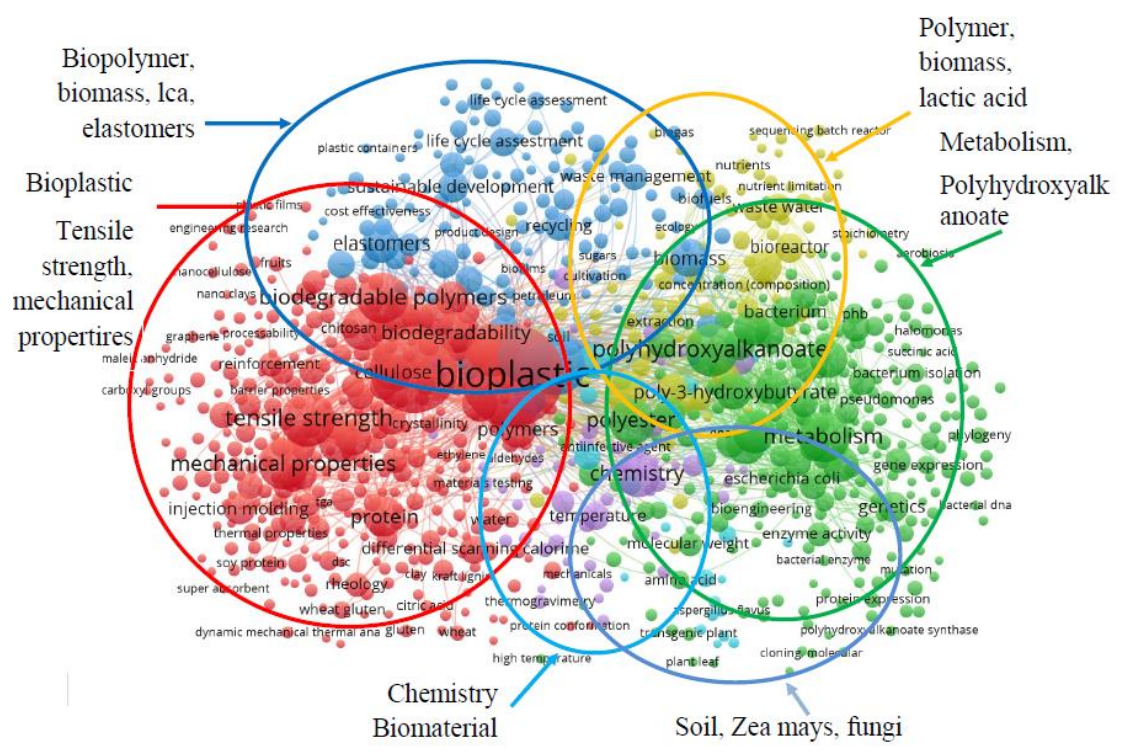

Figure 12. Worldwide occurrence at abstract and title level. 
The main cluster (in red, Figure 13) relates "bioplastic" with terms such as "reinforced plastic" [83], "tensile strength" [84], "mechanical properties" [85], and "injection molding" [86] and to all terms related to physical and processing properties. Moreover, "biodegradable polymers" [87] is found in this cluster, being this a very important characteristic of a bioplastic. "Bioplastic" and "reinforced plastic" are the terms with more weight and have a strong relatedness. These two terms have also links with the other clusters, with terms such as "polyhydroxyalkanate", "polymer" [88], "biomass", "life cycle assessment" [89], or "waste water" [90].

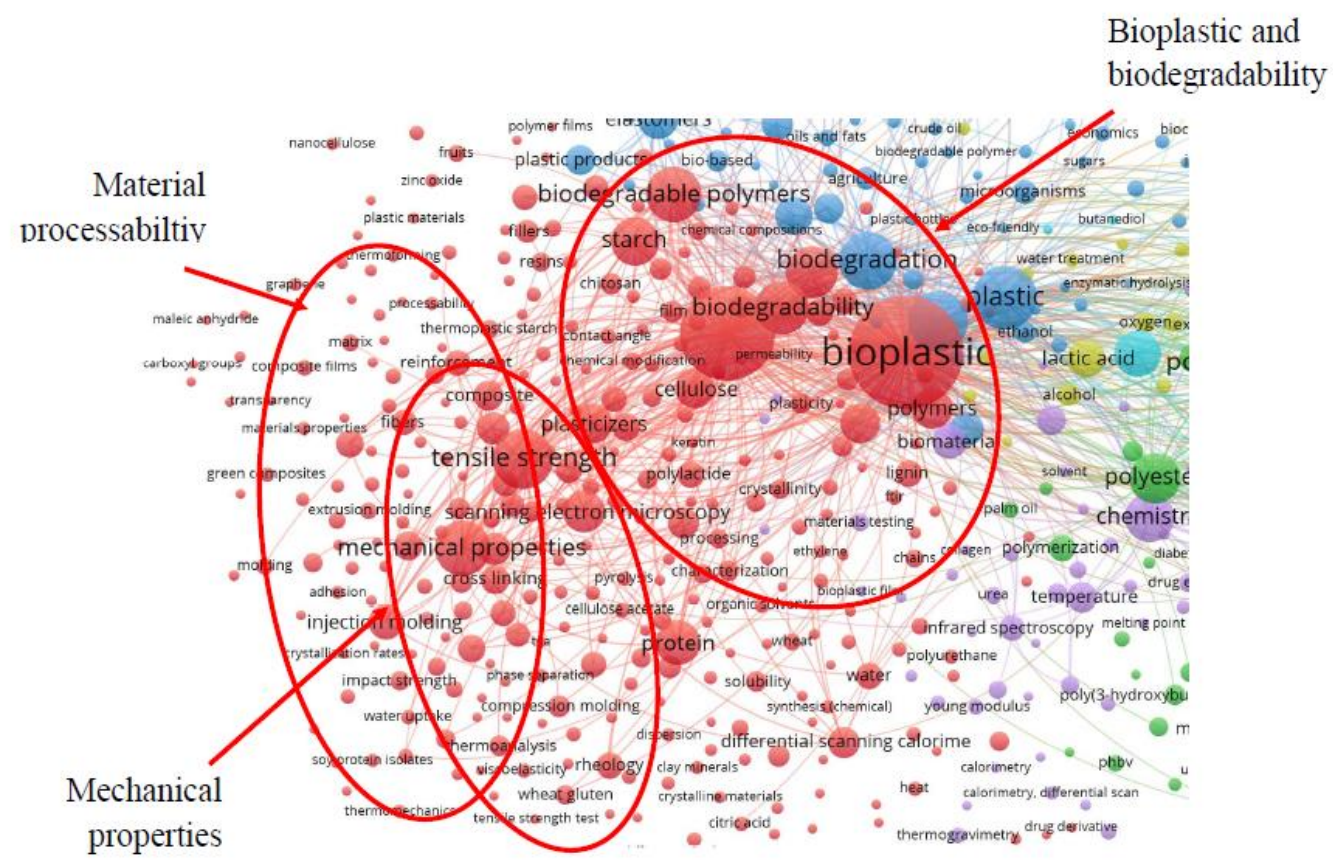

Figure 13. Main cluster of worldwide occurrence at abstract and title level, "bioplastic characterization".

Different areas can be found in this cluster. One is referring to "mechanical properties", with terms such as "tensile strength" or "impact strength". Others refer to "bioplastics" and "biodegradability"; another to "processability", "extrusion molding" [91], "injection molding" [86], or "compression molding" [92]; and a third to "bioplastic" and biodegradable terms, components to produce bioplastic ("starch" [93], "cellulose" [94], "lignin" [95], "chitosan" [96]), and "plasticizers" [97]. All these terms can be related to the topic "bioplastic characterization".

A second cluster (in green, Figure 14) relates the type of bioplastic material "polyhydroxykalkanoate", with other terms such as "metabolism" [98], "bacteria" [91], "glucose" [99], and "biosynthesis" [100]. All those terms are related to how to obtain this bioplastic. In addition "polyester", a traditional plastic that is substituted by this bioplastic, can be found in this cluster, probably because it is used as reference material in the research related to the new plastic type. All terms of this cluster refer to "bacterial bioplastic". 


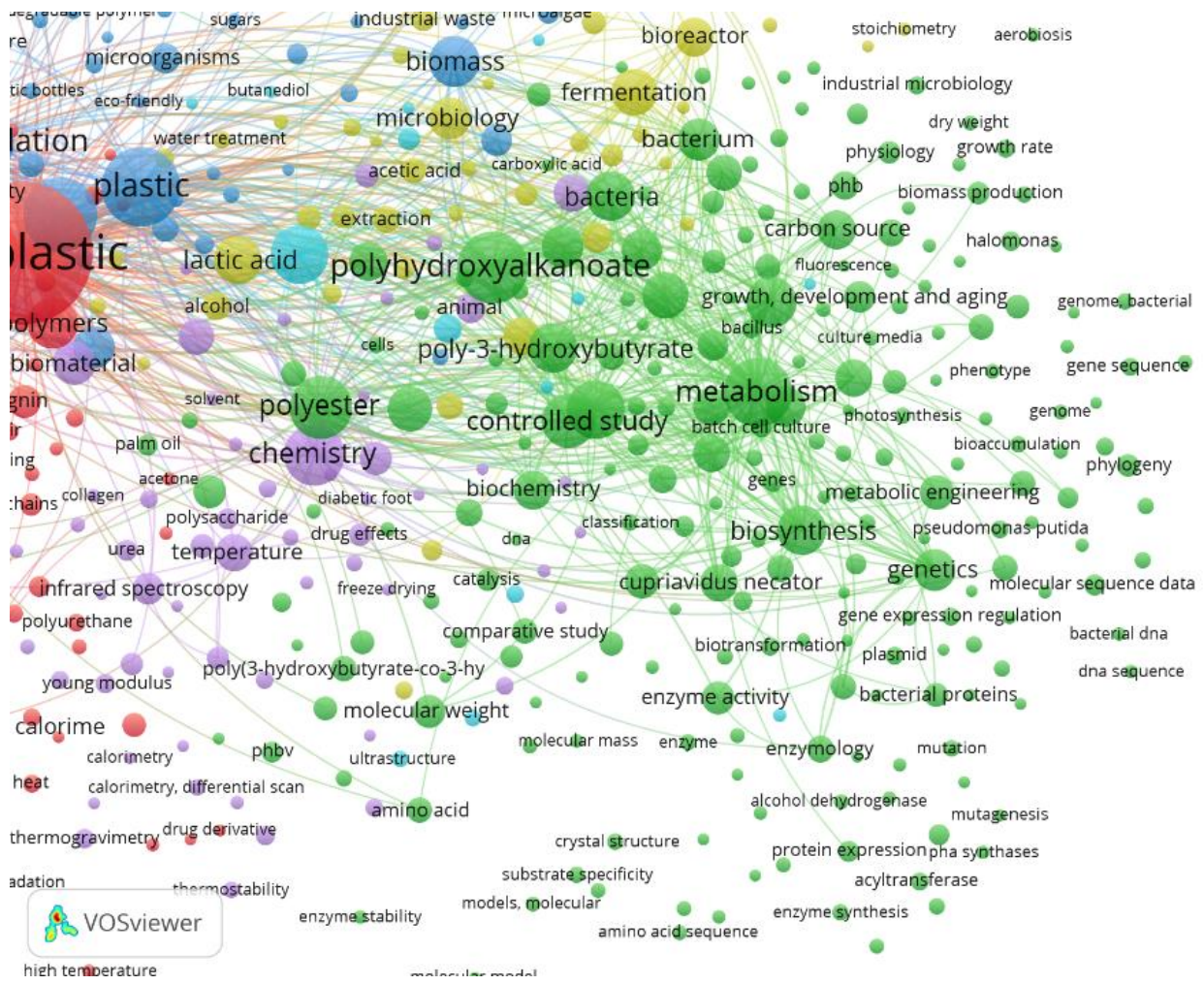

Figure 14. Second cluster of worldwide occurrence at abstract and title level.

In the center of the third cluster (in blue, Figure 15), "biopolymer" connected with "biodegradation" [101]; furthermore, connections with the conventional (from petrochemical raw material) material "plastic" can be found. These are connected with other terms such as "biodegradation", "recycling" [102], "waste management" [103], or "life cycle assessment". From the keywords "plastic" and "biopolymer", this cluster is connected to cluster 1 (red) and cluster 2 (green). All terms are related to "plastic biodegradation".

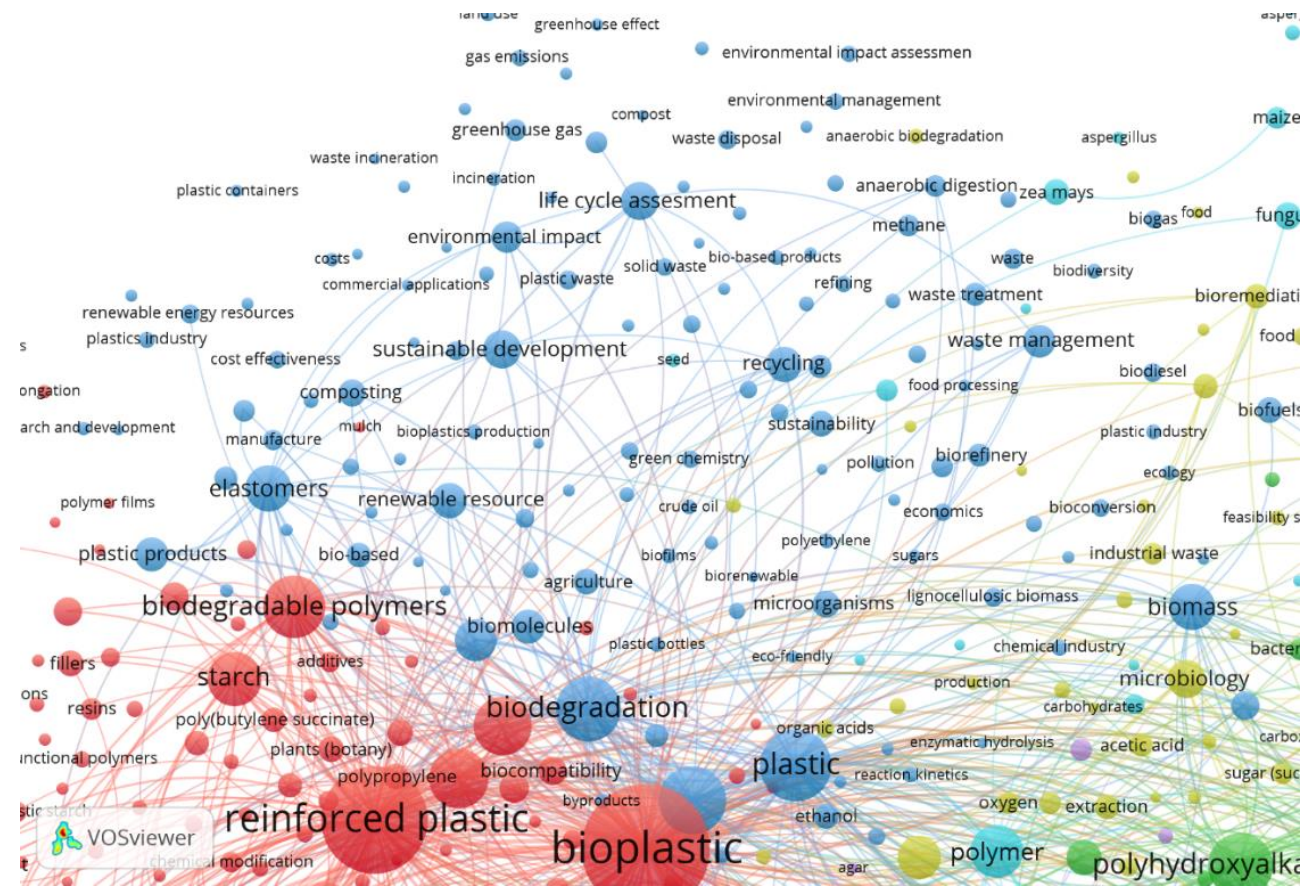

Figure 15. Third cluster of worldwide occurrence at abstract and title level. 
The fourth cluster (Figure 16), in yellow, has the keywords "biomass", "fermentation" [104], "microbiology" [105], "bacterium" [106], and "lactic acid" [107], among others. This cluster is connected mainly with clusters 1 and 2, but also has some connections with "plastic" or "biopolymer" from cluster 3. All terms are related to "biomass fermentation".

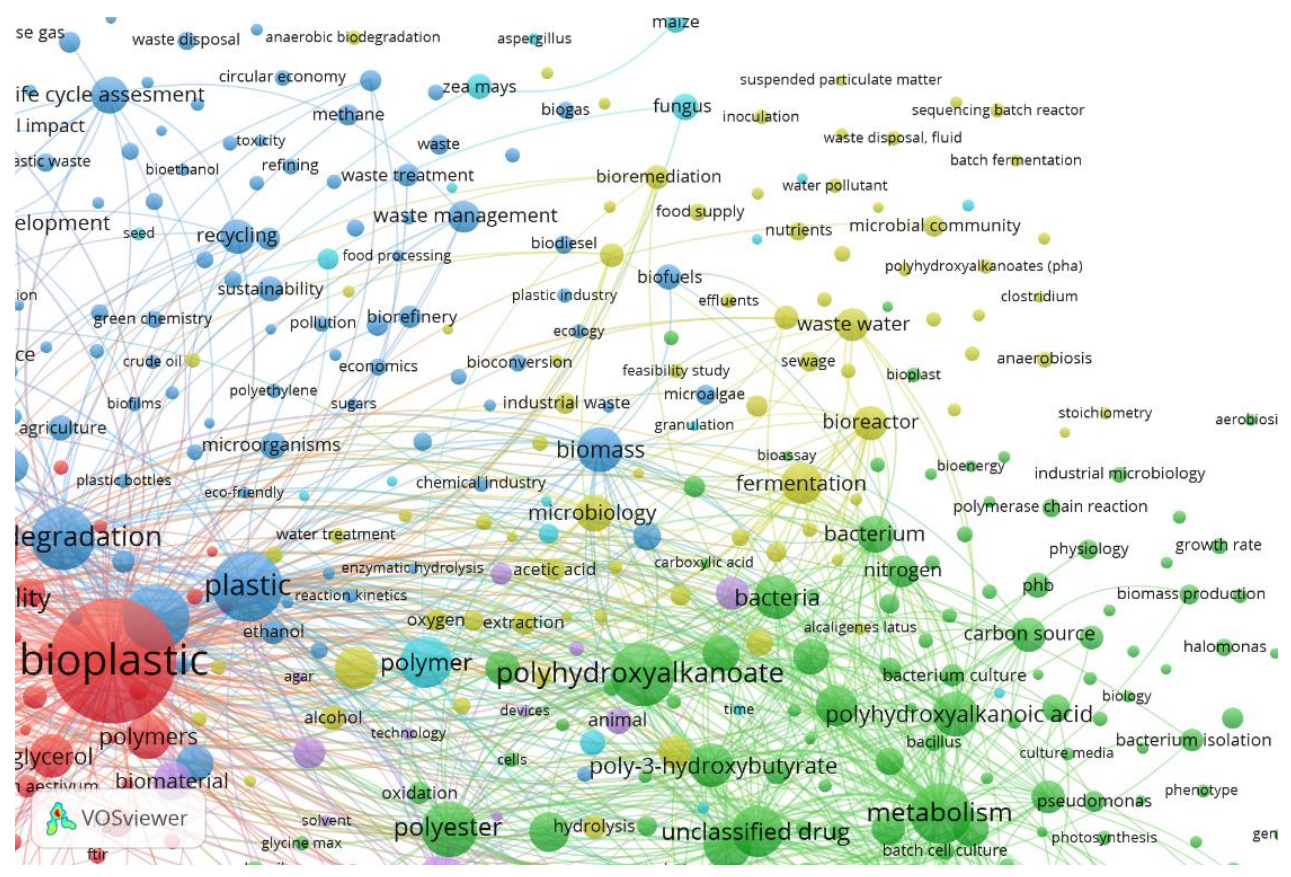

Figure 16. Fourth cluster of worldwide occurrence at abstract and title level.

Cluster 5 (Figure 17), in purple, has the term "chemistry" in its center. It includes keywords related to properties and chemical analysis terms, such as "temperature" [108], "melting point", or "infrared spectroscopy" [109]. This cluster also groups "biomaterial", "materials testing", or "biodegradable plastic". Through "chemistry", this cluster has very strong connections with clusters 1, 2, 3, and 4. All terms can be grouped around the concept "biomaterial properties".

The last cluster (Figure 18), in turquoise, contains "fungus", "maize", "zea mays" [110], "seed", or "soil". It is the smallest cluster with fewer connections to others. Those are terms related to components to obtain bioplastic, such as Zea mays. Corn (Zea mayz L.) has become one of the most consumed cereals in the world, with multiple applications for both nutritional and industrial purposes. It is used for the production of starch, since the grain is made up of approximately 70 to $75 \%$ of it, hence the reason to be used in the manufacture of plastics as a substitute for oil and its derivatives, which are nonrenewable resources [111]. In an investigation where corn starch bioplastic was made, it was shown that they can compete with plastics made from oil, because they have appropriate qualitative and physical characteristics, as well as a short degradation time of approximately 90 days [112]. It also links with terms such as "biofermentation", "bioreactor" [113], "microbial”, or "batch fermentation". All those terms related to "bioplastic production". 


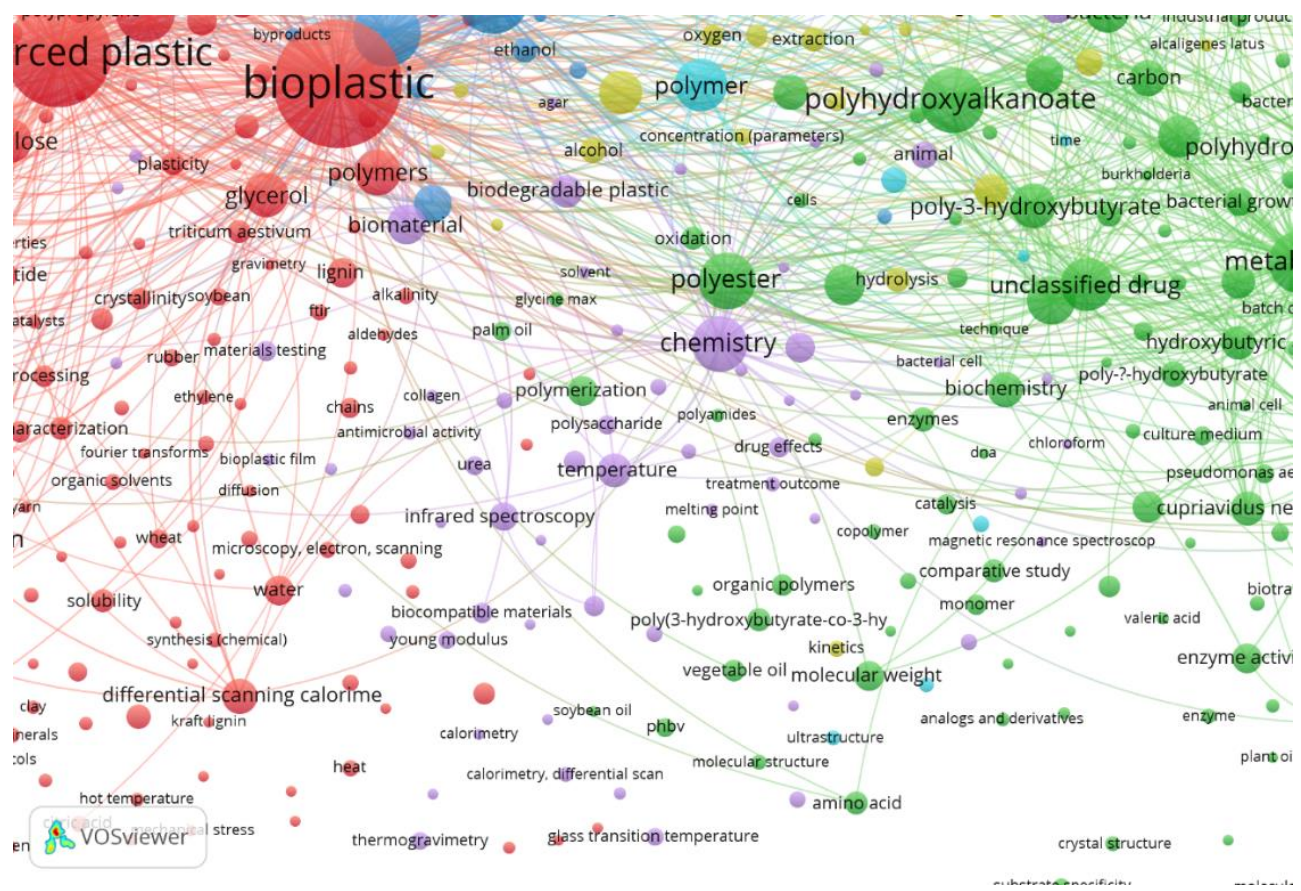

Figure 17. Fifth cluster of worldwide occurrence at abstract and title level.

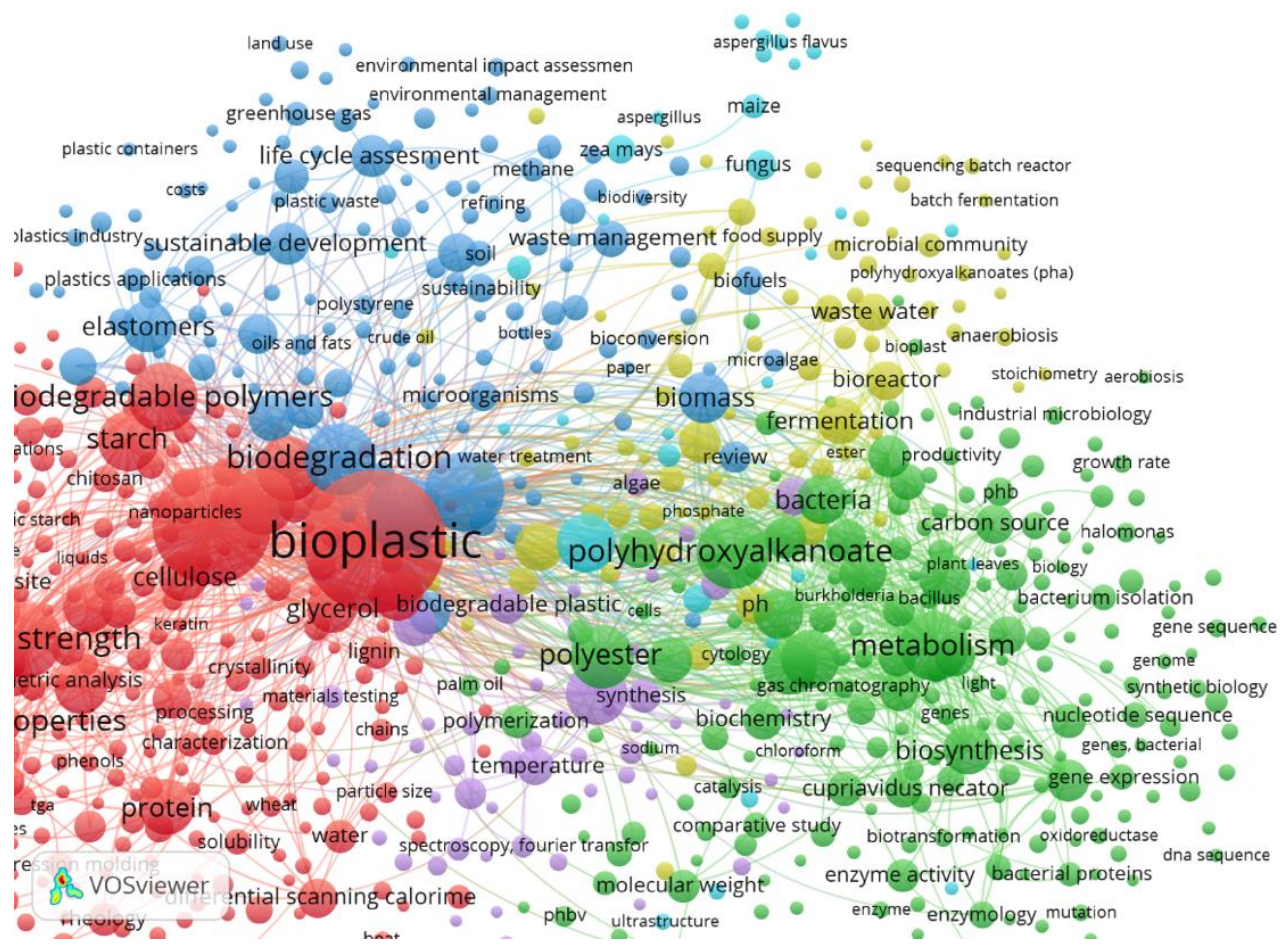

Figure 18. Sixth cluster of worldwide occurrence at abstract and title level.

Figure 19 is the co-occurrence for the United States. It shows four clusters, instead of six, analyzing it with number of co-occurrences to five (we will use this number with all the countries). The first cluster, in red, includes "mechanical properties", "tensile strength", or "reinforced plastic", all terms related with mechanical properties. Cluster 2, in green, presents "metabolism", "genetics" [98], "chemistry", or "Escherichia coli" [114]. A third cluster, in blue, includes the terms "bioplastic", "polyhydroxyalkanoate", or "life cycle 
assessment". The last cluster, in yellow color, includes terms such as "polymer" and "plastic" and how they can be obtained, "fungus", "maize", or "time factors".

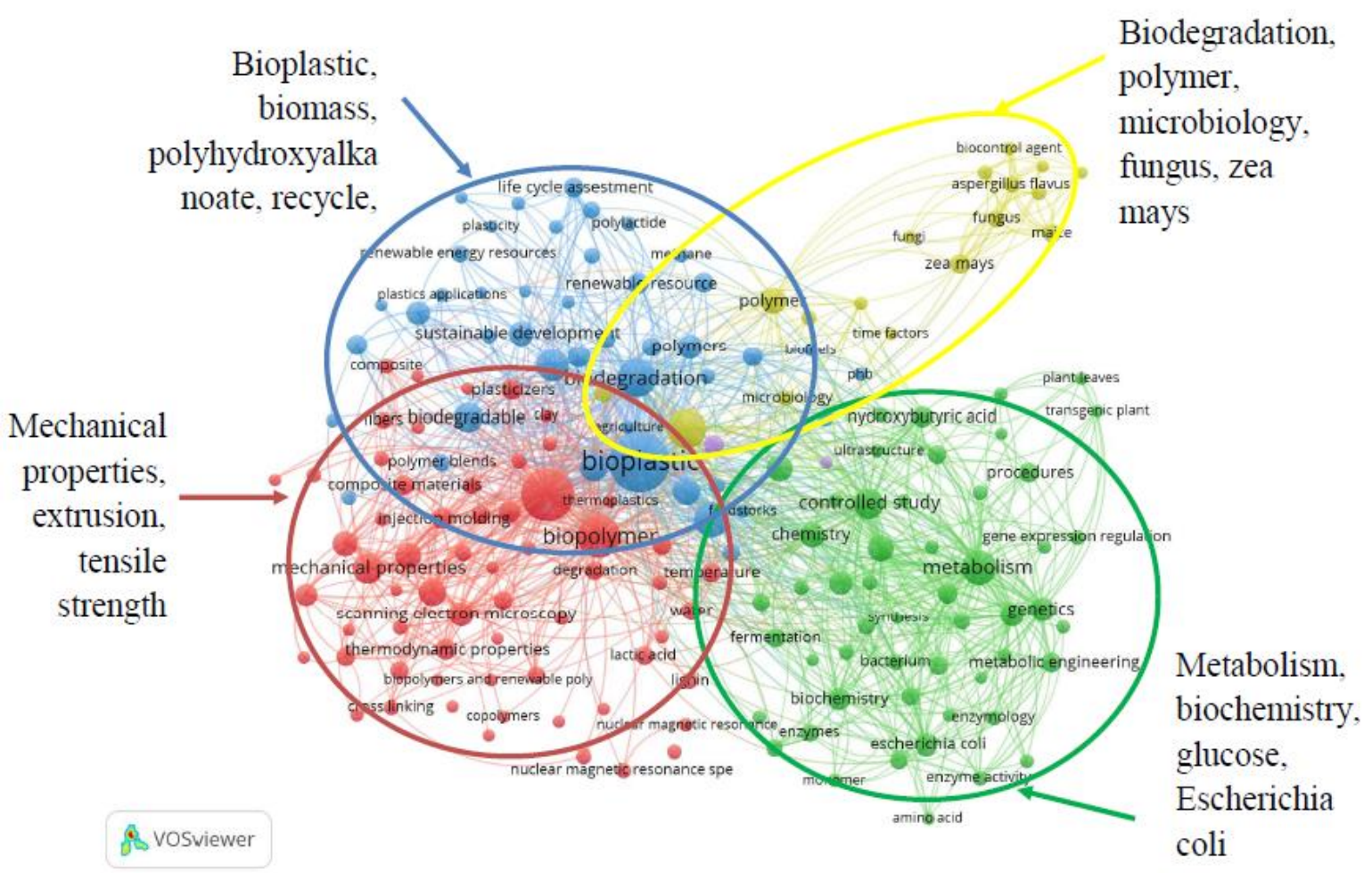

Figure 19. Word occurrence network: United States.

Analyzing Spain (Figure 20), six clusters are found. The main cluster, in red color, shows the term "bioplastic" as the most weighted term, related to "plastic", "polymer", "polyhydroxyalkanoate", "biopolymer", and "biomass". In this cluster, all main terms for bioplastic are grouped.

In a second cluster, in purple color, "reinforced plastic" is the principal term, and "protein" is the second one. Biodegradable and packaging terms can be found here. It is interesting to find "injection molding" and "elastic modulus", while "mechanical properties" and "molding" are in another cluster. The third cluster includes terms with "mechanical properties", and the fourth is about "rheology" [76]. In the fifth one, there are terms about "chemistry" and "biodegradation", and the last one is about "biodegradation".

In the India network map (Figure 21), three clusters are found. In the main cluster (red color), the term "polyhydroxyalkanoate" is the most weighted. Terms around this bacterial plastic, such as "biodegradation" or "biosynthesis", are found, but conventional terms, such as "polymer" or "polyester" [115], are also included here. In the second cluster (green color), "bioplastic" is the main term. "Tensile strength" is also in this cluster, together with other terms with such as "tensile strength" or "cellulose". In the third cluster (blue color), "chemistry", "bioreactor", or "biomass" are included. 


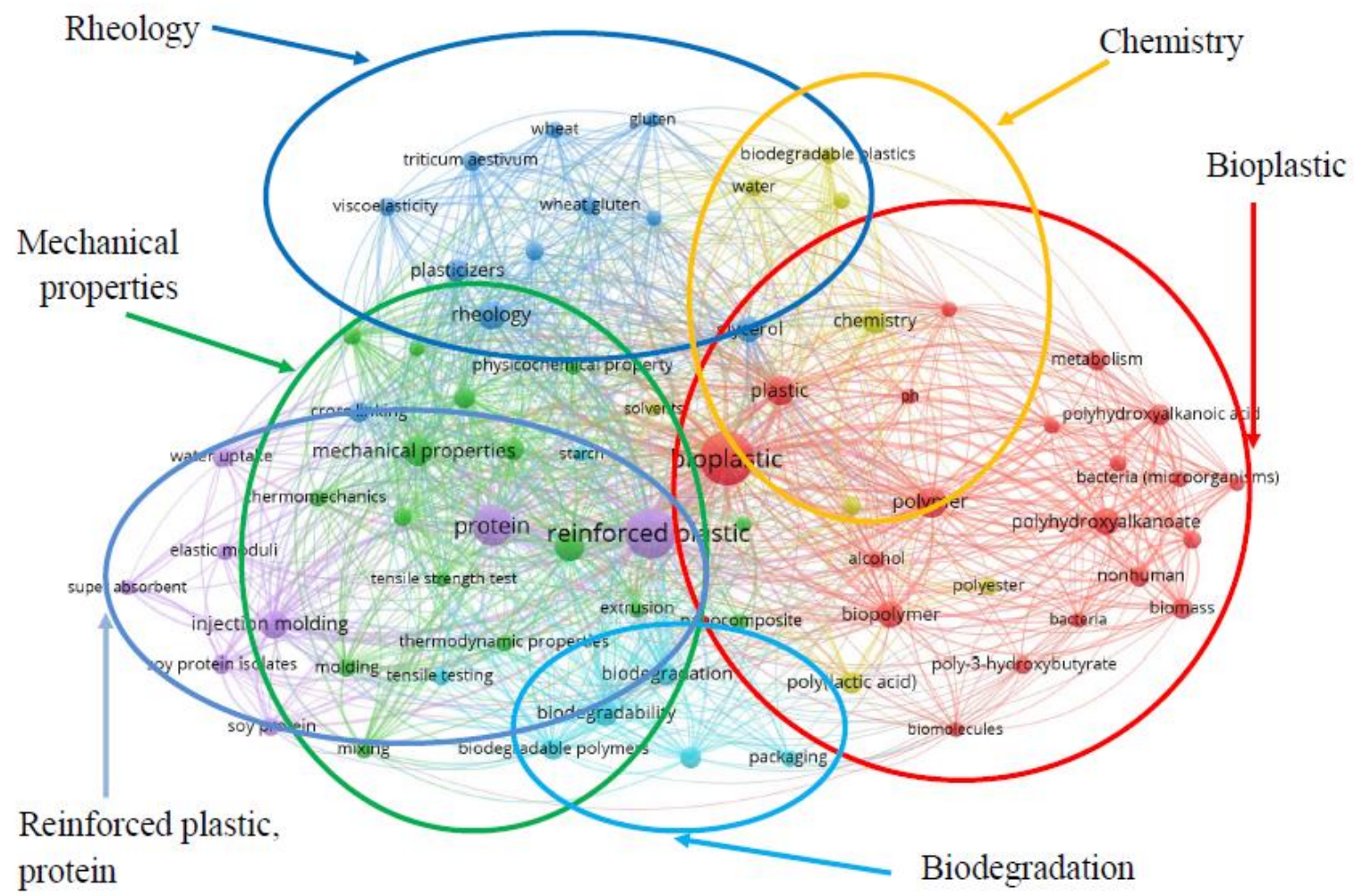

Figure 20. Word occurrence network: Spain.

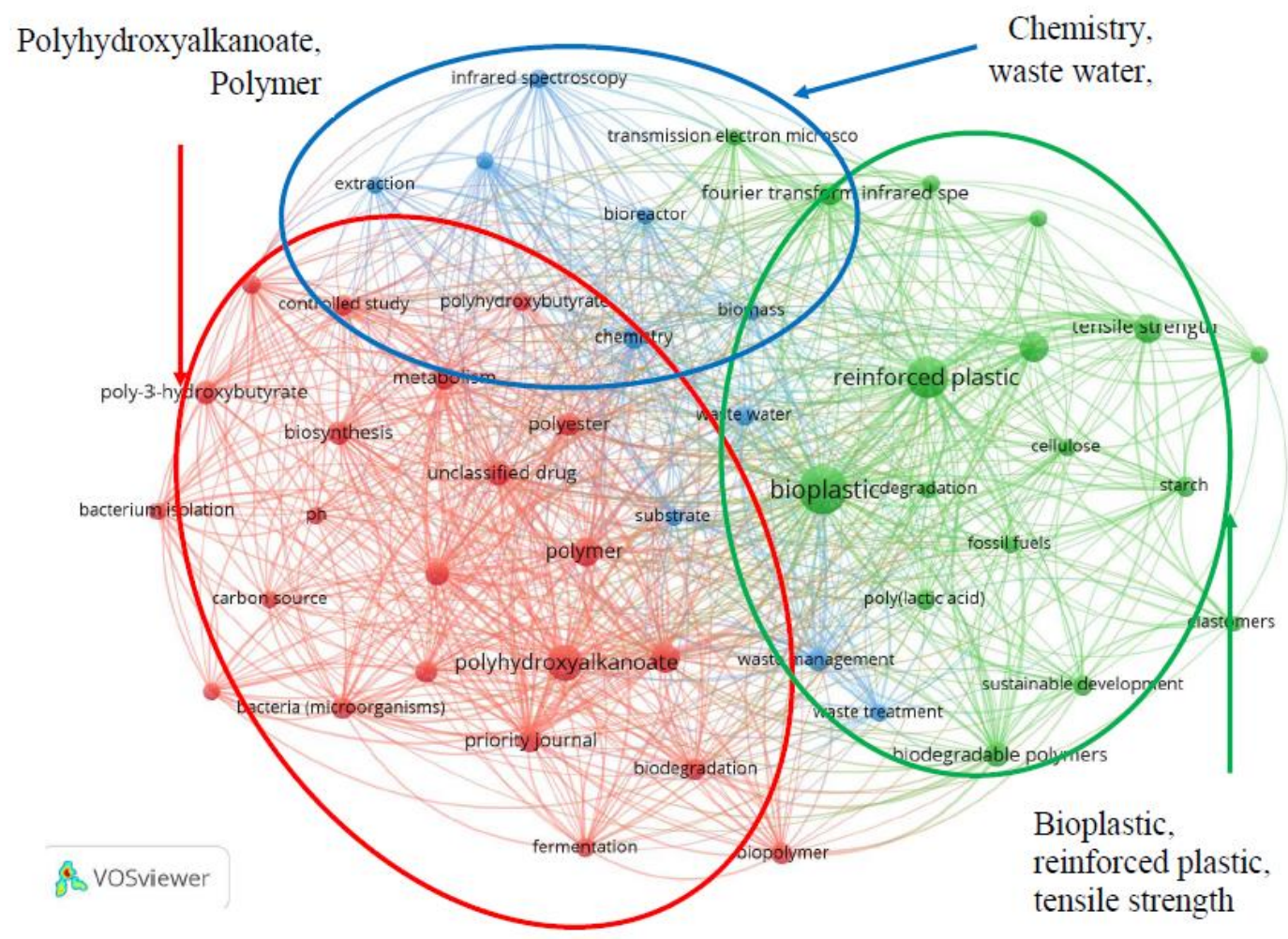

Figure 21. Word occurrence network: India.

In the Japan network map (Figure 22), five clusters, with a total of 57 keywords, are found. In the red cluster, "metabolism" and "genetics" are the main terms. It is in this 
cluster where "polyhydroxyalkanoate" can be found. In the green cluster, "bioplastic" is the main term. In this cluster are also mechanical references, such as "reinforced plastic", "tensile strength", or "heat resistance". In the blue cluster, bacterial plastic terms, substitutes for polyester, are listed: "bacteria", "polyester", "glucose" [99], or "bacterial growth". In the yellow cluster, "lactic acid and fermentation" is the most weighted keyword. Related terms, such as "microbiology", "biodegradation", or "methane" are found. Finally, in the purple cluster, "chemistry" and "biomass" can be found.

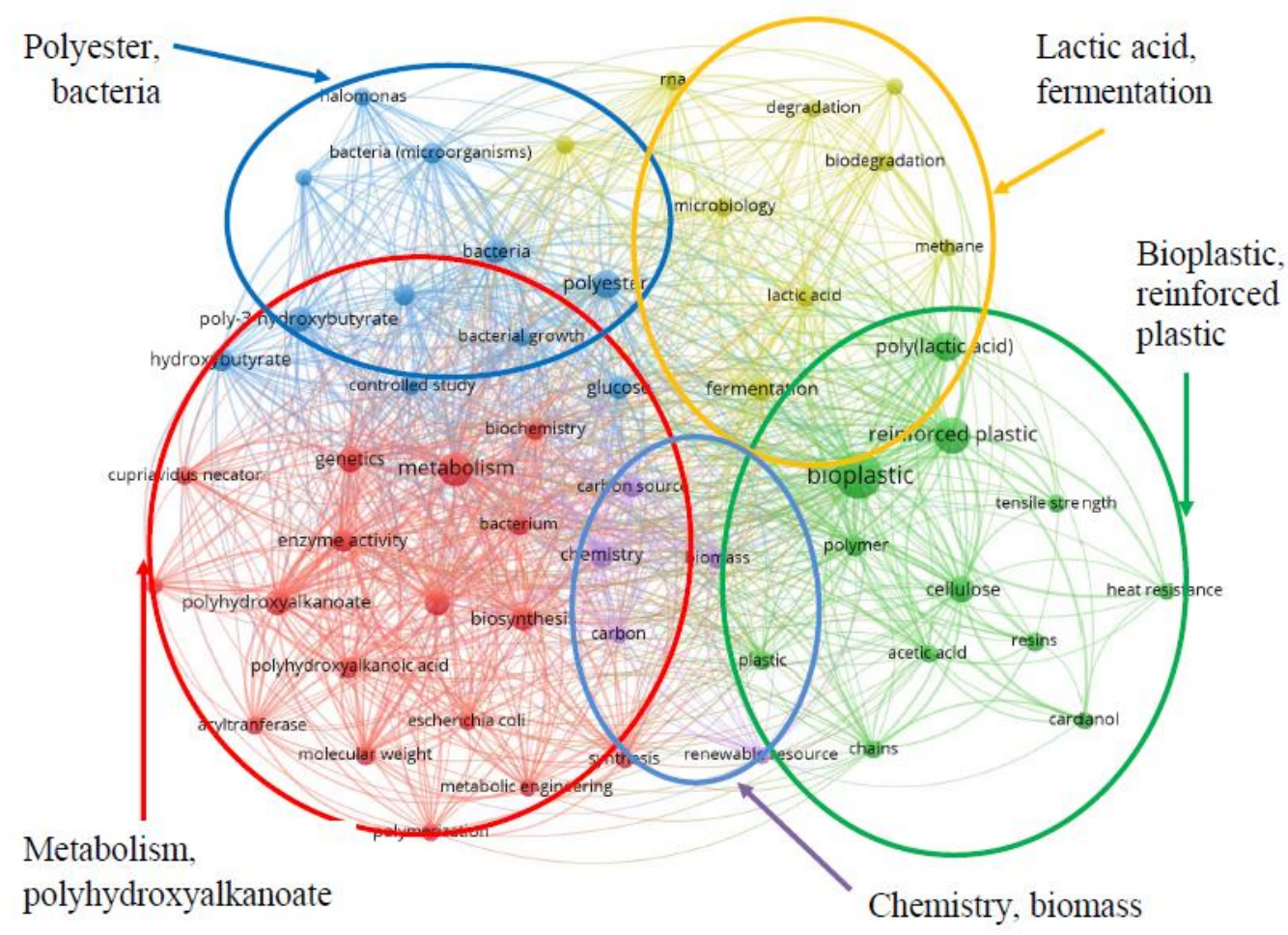

Figure 22. Word occurrence network: Japan.

In the Indonesia network map (Figure 23), four clusters, with a total of 37 keywords, are included. In the main cluster (red), "tensile strength" and "starch" can be found. It is this first country where "starch" can be found as a weighted word. It is also the first time that the mechanical properties are separated, with higher relatedness with plastics. In the green cluster, "bioplastic", "biodegradable polymers", and "mechanical properties" are included. In the third cluster (blue), "reinforced plastic" and "plasticizer", "glycerol" [80], or "elongation" can be seen. In the last cluster (yellow), "chitosan" [96] is found as the most weighted for the first time, and "fruits" and "elastomers" are included.

In the Italy network map (Figure 24), three clusters are found, with a total of 54 keywords with five minimum occurrences from 1209 keywords. The main cluster (red color) shows "reinforced plastic" as the main term, and "chemistry", "biopolymer", "polymer" and "carbon dioxide" are also included. In the second cluster (green color), "bioplastic" is the most weighted, with "biodegradation", life cycle assessment", "recycling", and "environment impact" also included. In the third cluster (blue color), "fungus", "zea mays" and "maize" are found. 


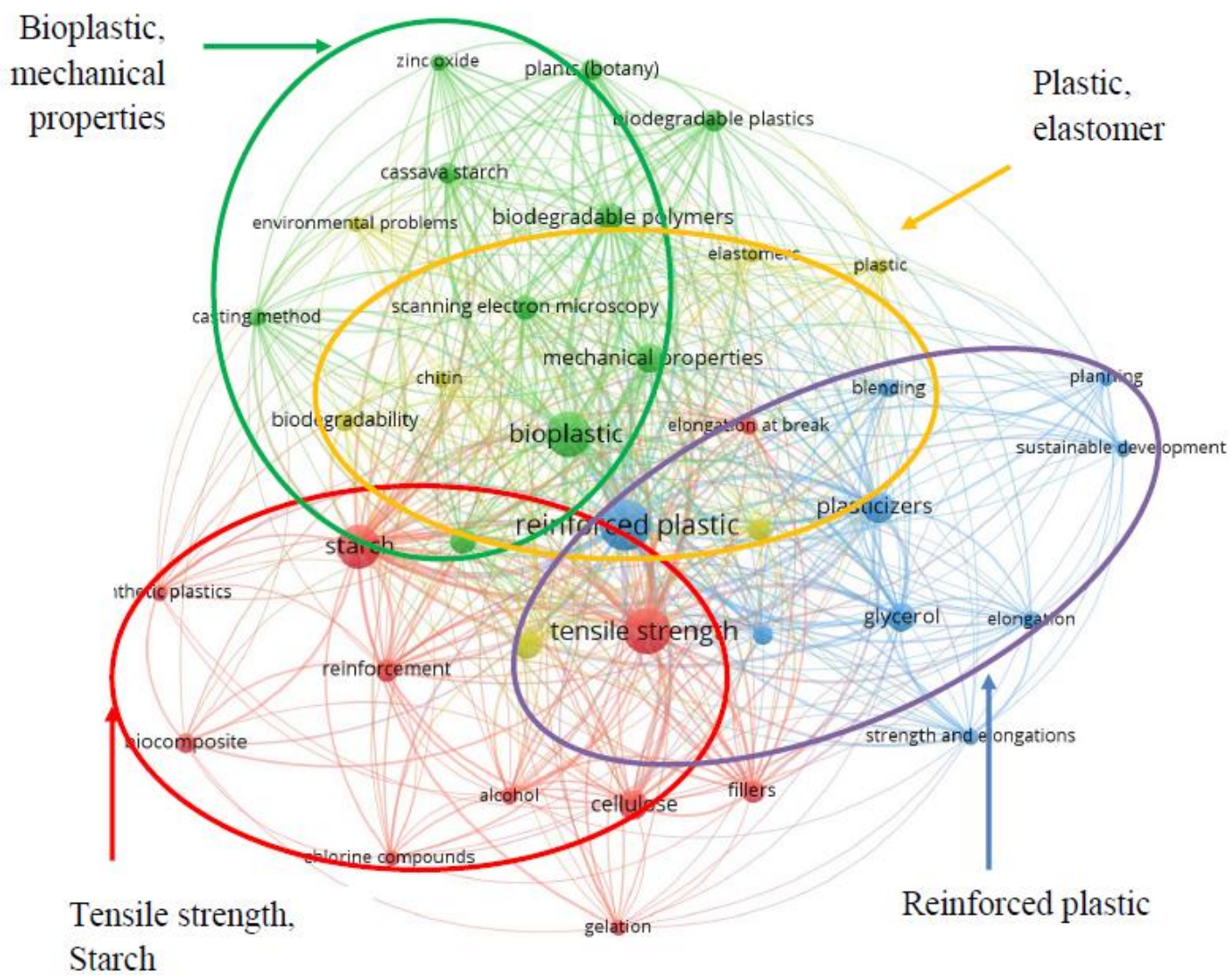

Figure 23. Word occurrence network: Indonesia.

In the Germany network map (Figure 25), the keywords are grouped in three clusters, with a total of 38 keywords with five minimum occurrences from 1203 keywords. In the main cluster (red color), "unclassified drug" is the most weighted term for the first time. It also lists "metabolism", "polyester", "controlled study", and "biosynthesis". In the second cluster (green) "bioplastic" is the main term, along with "reinforced plastic", "biodegradability", and "injection molding" found in this cluster. In the last cluster (blue color), "chemistry", "biotechnology" [116], and "biodegradation" are related to each other.

In the Thailand network map (Figure 26), three clusters are found, with a total of 26 keywords with five minimum occurrences from 809 keywords. In the main cluster (red color), "poly(lactic acid)" [117] is the most weighted term for the first time. In addition, "mechanical properties", "blending", or "biodegradable polymers" are included here. In the second cluster (green color), "reinforced plastic" is the main term, together with "tensile strength", "elongation at break", "glass transition" [108], or mechanical terms. In the last cluster (blue color), "bioplastic", "degradation [118], "plastic", or "polymer" are included.

In the China network map (Figure 27), a total of 44 keywords with five minimum occurrences from 1086 keywords are grouped in three clusters. In the main cluster (red color), "bioplastic" and "reinforced plastic" are presented as the most weighted terms. Again, "mechanical properties" or "tensile strength" are in the first cluster. In the second cluster (green color), "metabolism" is the most weighted term, with high relatedness with "chemistry", "biosynthesis", or "Escherichia coli". In the last cluster (blue), "unclassified drug" is found as the main term, related with "polyhydroxyalkanoate" or "bacterium". 


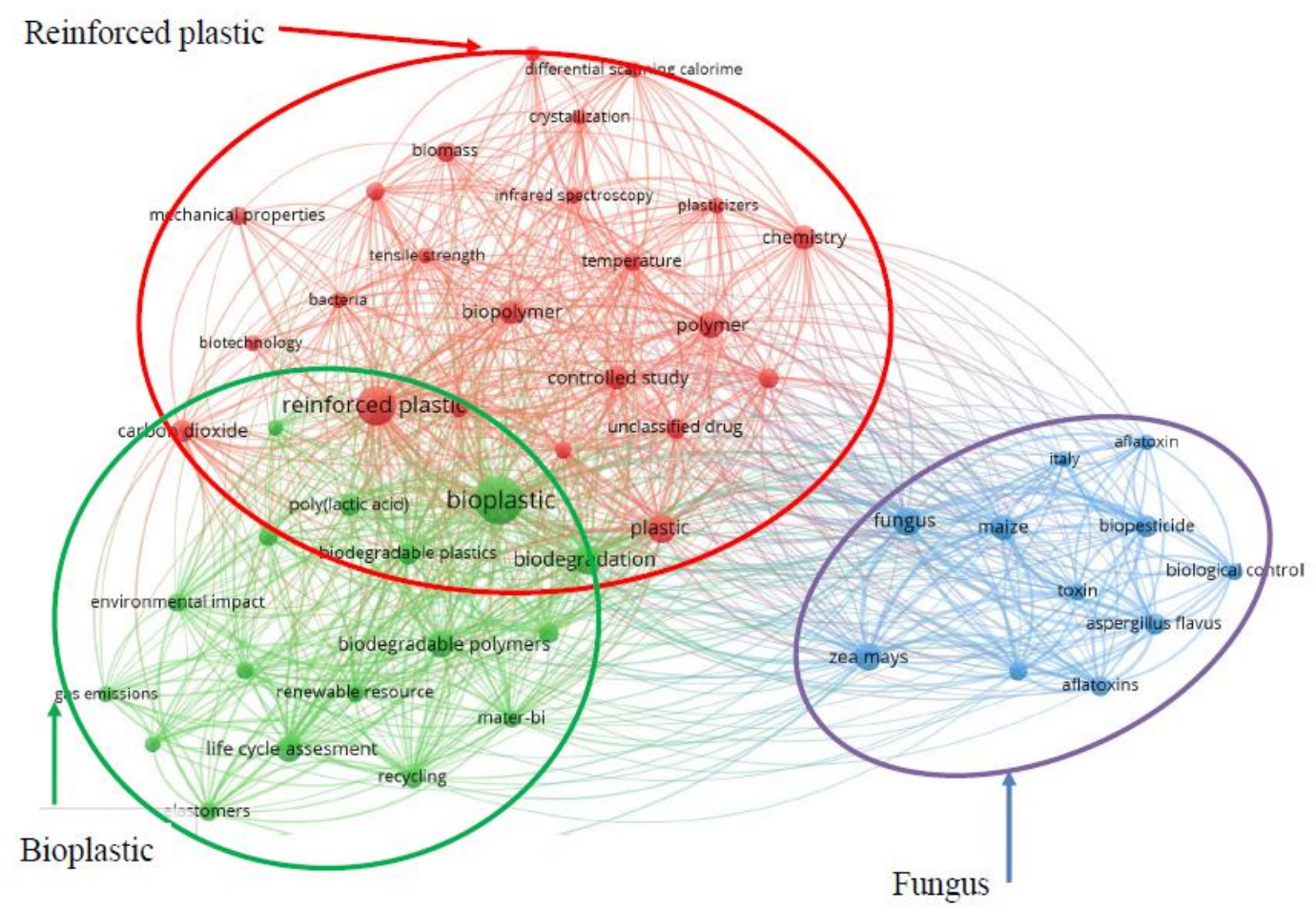

Figure 24. Word occurrence network: Italy.

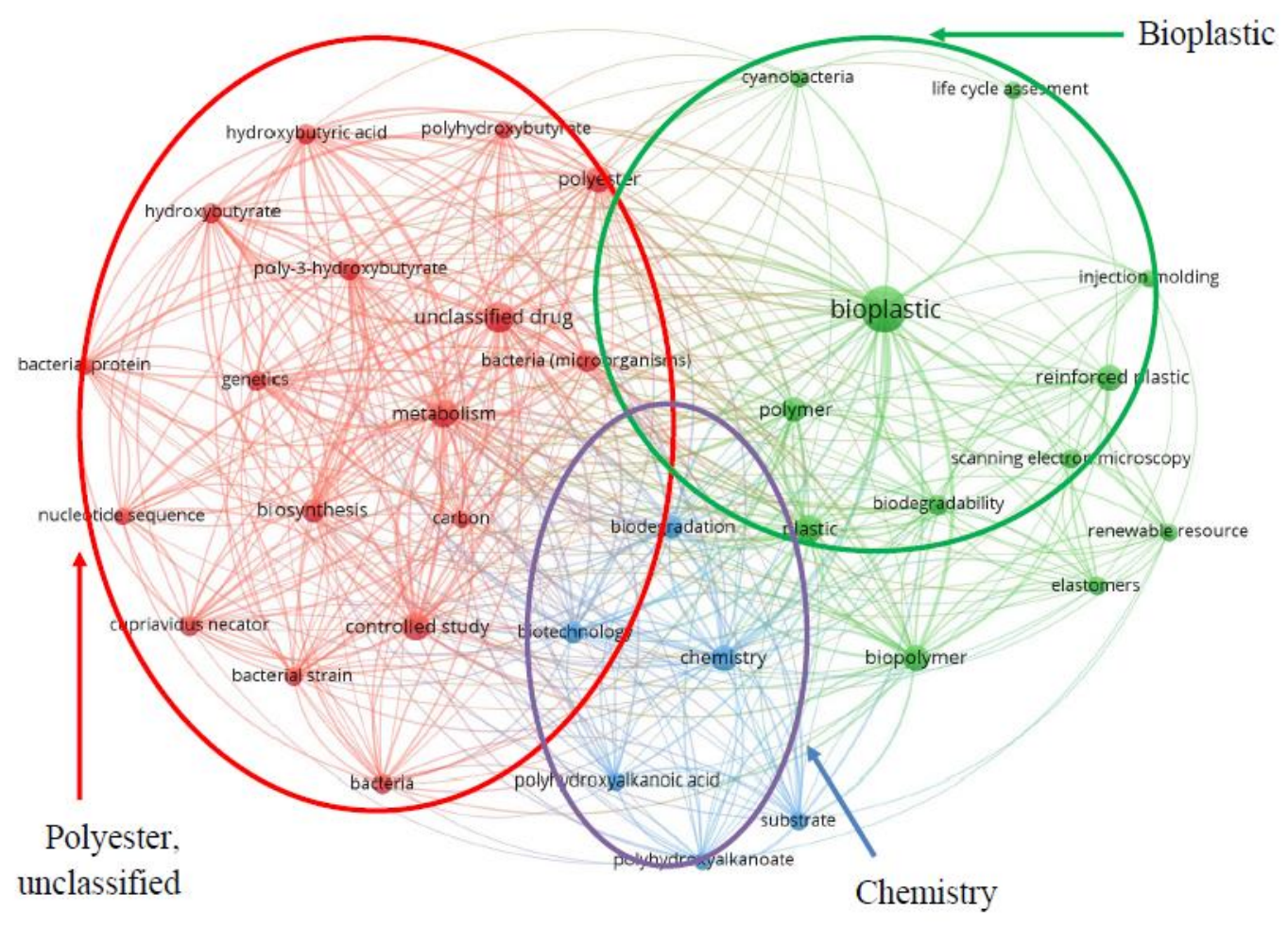

Figure 25. Word occurrence network: Germany. 


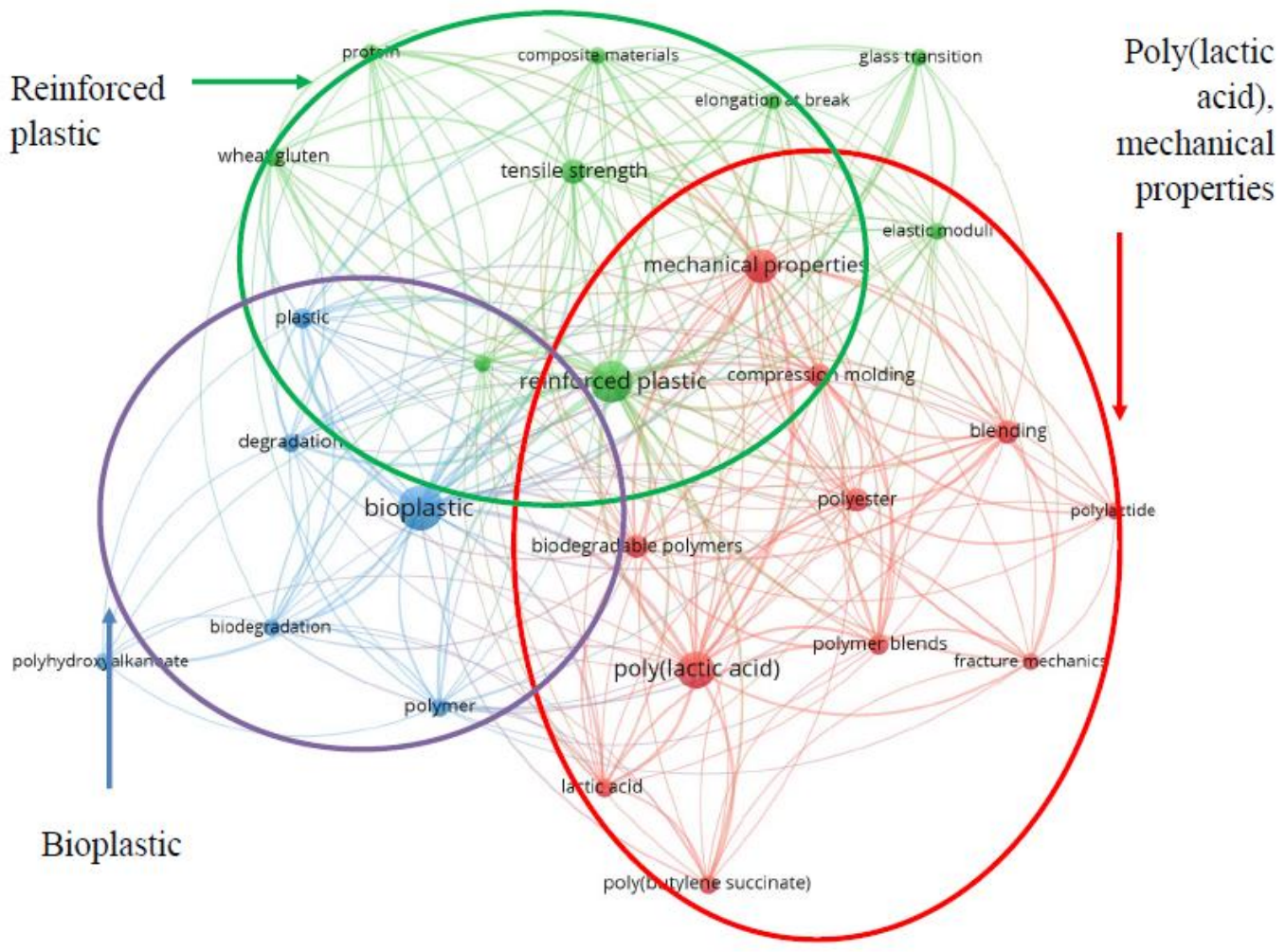

Figure 26. Word occurrence network: Thailand.

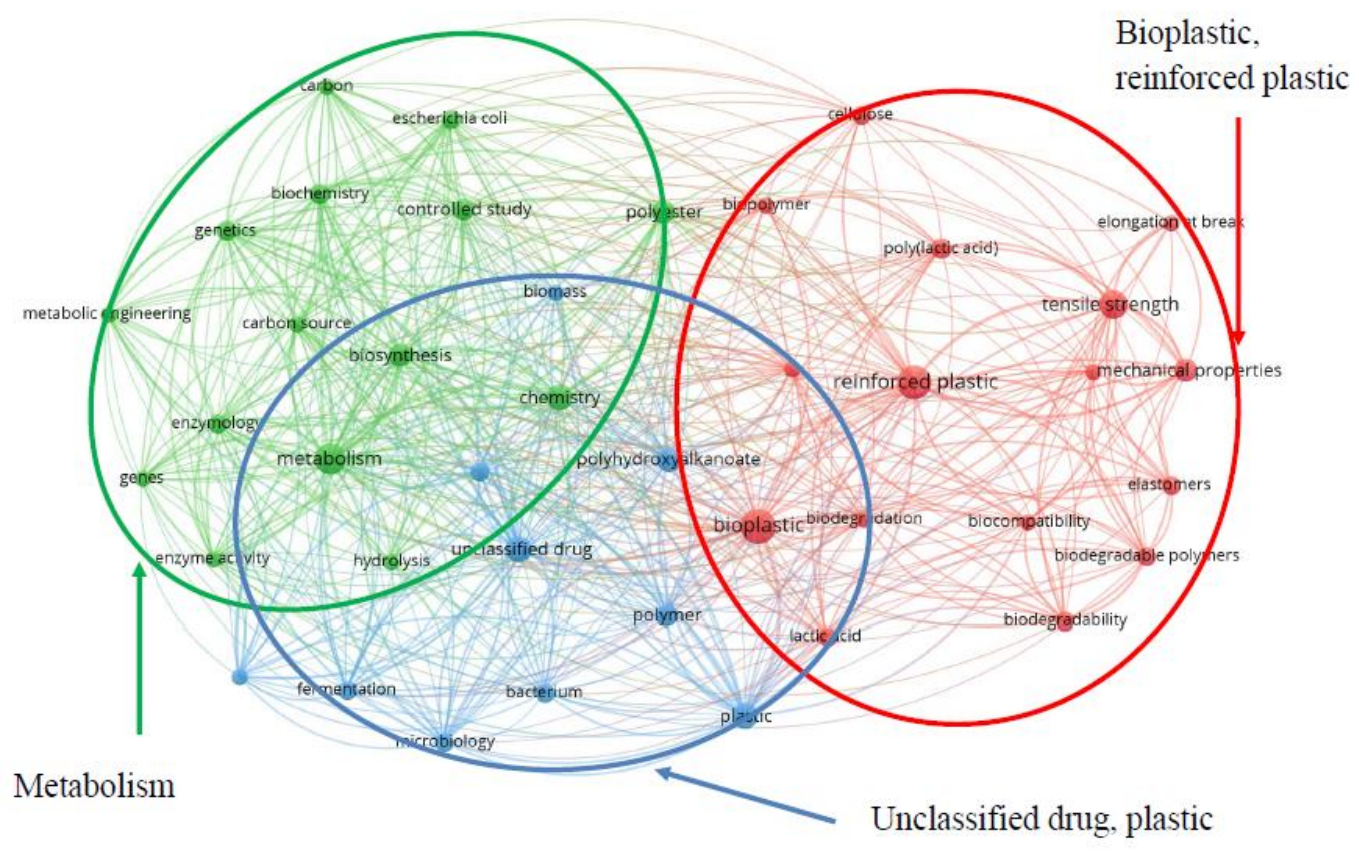

Figure 27. Word occurrence network: China.

In the Malaysia network map (Figure 28), there are again three clusters, with a total of 16 keywords with five minimum occurrences from 751 keywords. In the main cluster (red), "tensile strength" is found as the most weighted term. In the second cluster (green), it is "reinforced plastic", and, in the last cluster (blue), "bioplastic". 


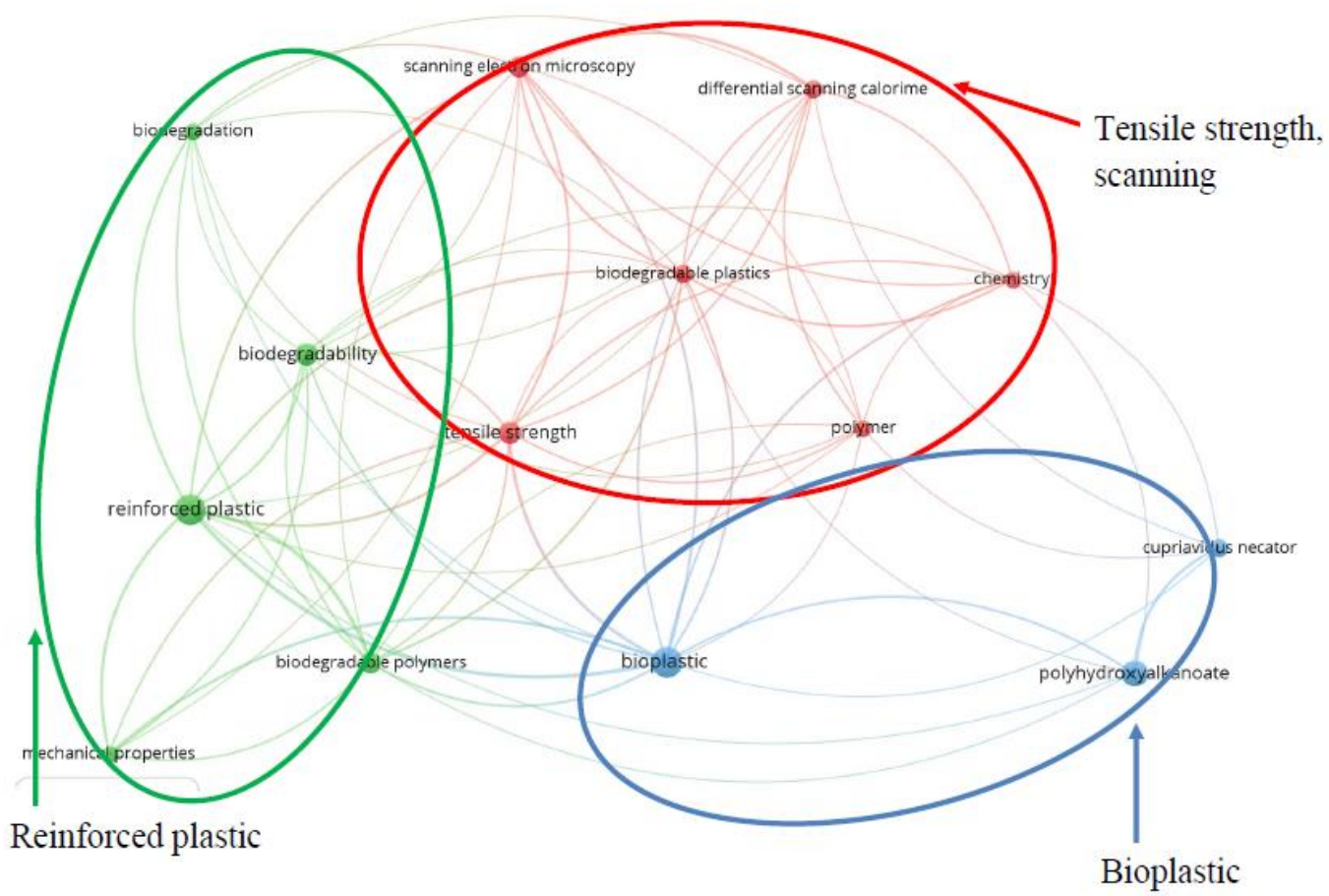

Figure 28. Word occurrence network: Malaysia.

\section{Discussion}

The first countries to investigate bioplastics were the United States, Spain, and Germany, but Germany today is not in the top 10 ranking countries in this field. Developing countries started to publish bioplastic documents around 2010 (Figure 5b).

Both the United States and Europe have specific strategies for bioeconomy, and more countries are creating their own ones. Developing countries have also created policies to work on bioeconomy. There is no worldwide act to develop bioplastics or bioeconomy. Support for biofuels is much greater than it is for biobased plastics, but bioplastics have an important role due to the potential to reduce petrol-based plastics.

The most investigated bioplastic is polyhydroxyalkanoate (PHA), a bacterial plastic. The second in importance is poly(lactic acid) (PLA). A term with important weight in almost all studied countries is reinforced plastic, since biobased plastics need reinforcements to improve their mechanical performance. The research on the mechanical properties of the newly developed plastics is also very important.

The first countries of the top 10 list have "bioplastic" as the main keyword, with "mechanical properties" in the same cluster. However, depending on the country, keyword relatedness is different. Italy has "reinforced plastic" as the main keyword, together with "chemistry". It is also the only country with "carbon dioxide" as an important keyword. Indonesia has "starch" and "chitosan" as important keywords. Thailand has "poly(lactic acid)" as the most weighted keyword, together with "mechanical properties" and "reinforced plastic". Germany has "unclassified drug" as main term in its main cluster. In the China network, "unclassified drug" is also a very important term, and it is the only country to have the bacteria "E. Coli" as a heavily weighted term, together with "mechanical properties". In Table 3, we have analyzed the 10 more important keywords, compared with the occurrence per country: 
Table 3. Occurrence of main keywords globally and per country.

\begin{tabular}{|c|c|c|c|c|c|c|c|c|c|}
\hline Country & 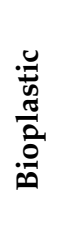 & 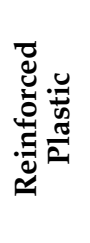 & 号点 & 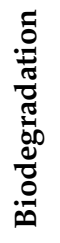 & 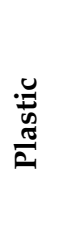 & 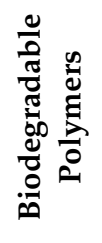 & 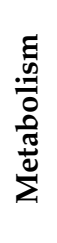 & 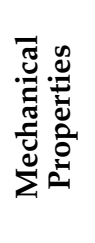 & 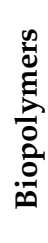 \\
\hline United States & 1 & 2 & 21 & 6 & 3 & 13 & 5 & 16 & 4 \\
\hline Spain & 1 & 2 & 7 & 18 & 4 & 25 & 24 & 6 & 10 \\
\hline India & 1 & 2 & 7 & 17 & 3 & 8 & 12 & - & 19 \\
\hline Japan & 1 & 2 & 32 & 29 & 34 & - & 3 & - & - \\
\hline Indonesia & 3 & 1 & 2 & 20 & 31 & 9 & - & 8 & - \\
\hline Italy & 1 & 2 & 52 & 3 & 5 & 6 & - & 31 & 11 \\
\hline Germany & 1 & 7 & & 13 & 5 & - & 3 & - & 6 \\
\hline Thailand & 1 & 2 & 5 & 17 & 10 & 8 & - & 4 & 25 \\
\hline China & 1 & 2 & 4 & 29 & 6 & 25 & 3 & 11 & 31 \\
\hline Malaysia & 1 & 2 & 4 & - & - & 6 & - & 12 & - \\
\hline
\end{tabular}

We find all the countries have "bioplastic" as the principal term except Indonesia, which has "reinforced plastic". Moreover, as second more important term, all countries except Indonesia and Germany, have "reinforced plastic". The rest of the terms vary depending on the country, since the research focus is different for each. Not all the terms are even present in all the countries. The keyword "metabolism" is only present in 6 of the 10 countries analyzed.

The main authors in this field are from Canadian universities, while Canada has published 3.3\% of the total documents. Only researchers from Spain, Italy, and the United States are also found in the top 10 list. M. Misra from the University of Guelph, Canada, is the author with more publications, together with a colleague from same university, Mr. A.K Mohanty. They have published $5 \%$ of all bioplastic documents and work together in $85 \%$ of their published documents. Spain has authors that have connections between different universities (University of Huelva and University of Seville), and Mr. L.T. Drzal from Michigan State has collaborated with University of Guelph.

When analyzing the countries connections worldwide, the United States is the most weighted country, with strong links with rest of the countries. However, if instead of each country, alone, we analyze the European Union together, its resulting weight is greater than that of the United States.

Looking at the ratios studied, Spain has the highest one in documents per million inhabitants (2.195). India is the country with more documents compared with GDP (11.48), while Japan is the country with more researchers per million inhabitants (5194.8).

This study shows that research for bioplastic in each country started in different timeframes (Figure $5 b$ ). This figure presents the number of occurrences of appearance per year and per country according to the references obtained from the Scopus search. The figure shows that most research carried out was after 2010. This study also shows an interest in bioplastics and, more specifically, for bioeconomy as a route to industrialize the ecology.

This study researched governments policies and the tendency of documents per year published, as shown in Figure 5. China began bioplastic documents publication in 2006. Looking at the different bioeconomic policies, it was after the Medium-to Long-Term Plan that this field was researched intensively. The United States growth was in 2004, two years after the BioPreferred program. This growth continued with The National Bioeconomy Blueprint in 2012. 
Germany's growth has two main dates: starts in 2010, four years after the first cluster strategy, and it continued in 2016, five years after the National Research Strategy Bioeconomy 2030 publication. The country had a transition in 2015, with two documents published between both policies.

Japanese Biomass Nippon Strategy started in 2002, but growth in documents started in 2011. We can link this increase to the first revision done in 2006. Japan has a certification program for bioplastics, created by the Japan BioPlastics Association. Spain has several initiatives, but first one was the BIOPLAT, in 2007. Spanish growth started in 2011, four years after this initiative. India created several initiatives, but it was just after the National Biotechnology Development Strategy (2015), that its growth started (2016). Malaysia increased the published documents in 2012, two years after the National plan. However, it was in 2018 when Malaysia reached the maximum documents per year. Malaysia had already created plans in 2005, but it was after the National plan when Malaysia increased the documents to more than 10 per year. Italian strategy focuses on clusters, combination of public and private initiatives. In 2012, the Ministry of Education, Universities, and Research launched a call. Italian growth started after this. Indonesia growth started in 2017, two years after the Grand Strategy of Agricultural Development. Thailand published the National Roadmap for the Development of Bioplastics Industry in 2008, and it was five years after that first document was published, in 2008. Growth started in 2013, with eight publications. In conclusion, it is between two and five years after a government plan that it bears fruit.

\section{Conclusions}

This paper evaluates the global research trends in bioplastic publications from 1984 to 2019. The topic of bioplastics has been a field with extensive research during the last 20 years, but the publication output has increased exponentially since 2010 . There is a growing interest in the research related to it, which corresponds to the urgent need for ecologic development and life improvement and to the policies on the topic appearing worldwide.

The connection between countries and several ratios to find a connection between these investigations, governmental policies, and economy shows that the country with more documents published is Unites States of America, followed by Spain. It is also the United States that was the first country to publish articles. According to the ratios studied, the research on bioplastic has a big impact in Spain compared with other countries. Primarily, University of Huelva and University of Seville are focused on bioplastics; these two universities have links together.

The main authors in this field are from Canada, although this country is the 11th in terms of number of publications. M. Misra and A.K. Mohanty published a 5\% of all published documents.

Based on the co-keyword network analysis, the main research areas that can be found in the domain of bioplastics are (a) bioplastic characterization; (b) bacterial plastic; (c) plastic biodegradation; (d) biomass fermentation; (e) biomaterial properties; and (f) bioplastic production.

The keyword analysis on different countries shows a heterogeneous distribution. The main term is "bioplastic" in all countries except Indonesia. The second keyword with more weight is "reinforced plastics". The first countries to start publishing have a similar keyword distribution, as the main research areas pointed out above, while the last countries to work on this topic, such as Malaysia or Thailand, focus on specific fields such as "reinforced plastics". Germany and China have "unclassified drug" as very weighted word, which is different from the main research areas.

There is no global worldwide research; each country is doing research on its own topics. Even though there is a European and a worldwide bioplastic association, there is no global action at the research level. As analyzed, there are few policies dedicated to bioplastics, which have a relative disadvantage compared to biofuels. The only policies specifically for bioplastics applied commonly in different countries are those concerned 
with the use of biodegradable plastic bags. Japan and India are countries with specific bioplastic policies.

This study also analyzes the connection between policies and publication years, leading to the conclusion that it takes between two and five years for a strategy implementation to have an effect on the documents published.

There is a limitation to find specific bioplastic policies for different governments. Based on that, a deeper content analysis is recommended for further research.

Author Contributions: Conceptualization, L.F.C.; methodology, L.F.C.; formal analysis, V.F.; investigation, R.G.; resources, L.F.C.; data curation, L.F.C.; writing—original draft preparation, R.G.; writing-review and editing, V.F. and L.F.C.; visualization, R.G.; supervision, V.F. and L.F.C.; project administration, L.F.C.; funding acquisition, V.F. and L.F.C. All authors have read and agreed to the published version of the manuscript.

Funding: This work is partially supported by ICREA under the ICREA Academia program.

Institutional Review Board Statement: Not applicable.

Informed Consent Statement: Not applicable.

Data Availability Statement: Data is available from the corresponding authors upon request.

Acknowledgments: The authors at the University of Lleida would like to thank the Catalan Government for the quality accreditation given to their research group GREiA (2017 SGR 1537). GREiA is a certified agent TECNIO in the category of technology developers from the Government of Catalonia.

Conflicts of Interest: The authors declare no conflict of interest.

\section{References}

1. Thompson, R.C.; Moore, C.J.; vom Saal, F.S.; Swan, S.H. Plastics, the environment and human health: Current consensus and future trends. Philos. Trans. R. Soc. B Biol. Sci. 2009, 364, 2153-2166. [CrossRef]

2. Pei, L.; Schmidt, M.; Wei, W. Conversion of Biomass into Bioplastics and Their Potential Environmental Impacts. Biotechnol. Biopolym. 2011. [CrossRef]

3. European Bioplastics, What Are Bioplastics? Material Types, Terminology, and Labels—An Introduction. 2018. Available online: https:// docs.european-bioplastics.org/publications/fs/EuBP_FS_What_are_bioplastics.pdf (accessed on 1 June 2021).

4. Laycock, B.; Halley, P.; Pratt, S.; Werker, A.; Lant, P. The chemomechanical properties of microbial polyhydroxyalkanoates. Prog. Polym. Sci. 2014, 39, 397-442. [CrossRef]

5. Meereboer, K.W.; Misra, M.; Mohanty, A.K. Review of recent advances in the biodegradability of polyhydroxyalkanoate (PHA) bioplastics and their composites. Green Chem. 2020, 22. [CrossRef]

6. Gumel, A.M.; Annuar, M.S.M.; Heidelberg, T.; Gumel, A.M.; Annuar, M.S.M.; Heidelberg, T. Biosynthesis and Characterization of Polyhydroxyalkanoates Copolymers Produced by Pseudomonas putida Bet001 Isolated from Palm Oil Mill Effluent. PLoS ONE 2012, 7, e45214. [CrossRef]

7. Araújo, T.R.; Petkowicz, C.L.D.O.; Cardoso, V.L.; Filho, U.C.; Vieira, P.A. Biopolymer production using fungus Mucor racemosus Fresenius and glycerol as substrate. Polimeros 2016, 26, 144-151. [CrossRef]

8. Kaparapu, J. Polyhydroxyalkanoate (PHA) Production by Genetically Engineered Microalgae: A Review Jyothi Kaparapu. J. New Biol. Rep. 2020, 7, 68-73.

9. Mohapatra, S.; Maity, S.; Dash, H.R.; Das, S.; Pattnaik, S.; Rath, C.C.; Samantaray, D. Bacillus and biopolymer: Prospects and challenges. Biochem. Biophys. Rep. 2017, 12, 206-213. [CrossRef]

10. Sav, A.R.; Mittal, A.K.; Thorat, A.A.; Dubey, S.; Banerjee, U.C. A Comparative study on the production of PHA by three different Pseudomonas sp. Int. J. Curr. Microbiol. Appl. Sci. 2014, 3, 940-954.

11. Ojha, N.; Das, N. Optimization and Characterization of Polyhydroxyalkanoates and its Copolymers Synthesized by Isolated Yeasts. Res. J. Pharm. Technol. 2017, 10, 861. [CrossRef]

12. Johnsson, N.; Steuer, F. Bioplastic Material from Microalgae: Extraction of Starch and PHA from Microalgae to Create a Bioplastic Material. 2018. Available online: http:/ /www.diva-portal.org/smash/record.jsf?pid=diva2\%3A1228894\&dswid=-2569 (accessed on 1 June 2021).

13. Jem, K.J.; Tan, B. The development and challenges of poly (lactic acid) and poly (glycolic acid). Adv. Ind. Eng. Polym. Res. 2020, 3, 60-70. [CrossRef]

14. Henton, D.; Gruber, P.; Lunt, J.; Randall, J. Polylactic Acid Technology. Nat. Fibers Biopolym. Biocompos. 2005, 16, 527-577. [CrossRef]

15. Tang, X.; Alavi, S.; Herald, T.J. Effects of plasticizers on the structure and properties of starch-clay nanocomposite films. Carbohydr. Polym. 2008, 74, 552-558. [CrossRef] 
16. Teixeira, E.D.M.; Curvelo, A.A.; Corrêa, A.C.; Marconcini, J.M.; Glenn, G.M.; Mattoso, L.H. Properties of thermoplastic starch from cassava bagasse and cassava starch and their blends with poly (lactic acid). Ind. Crops Prod. 2012, 37, 61-68. [CrossRef]

17. Schwach, E.; Avérous, L. Starch-based biodegradable blends: Morphology and interface properties. Polym. Int. 2004, 53, 2115-2124. [CrossRef]

18. Priya, B.; Gupta, V.K.; Pathania, D.; Singha, A.S. Synthesis, characterization and antibacterial activity of biodegradable starch/PVA composite films reinforced with cellulosic fibre. Carbohydr. Polym. 2014, 109, 171-179. [CrossRef] [PubMed]

19. Soares, F.C.; Yamashita, F.; Müller, C.; Pires, A.T. Effect of cooling and coating on thermoplastic starch/poly(lactic acid) blend sheets. Polym. Test. 2014, 33, 34-39. [CrossRef]

20. Bendaoud, A.; Chalamet, Y.; Bendaoud, A.; Chalamet, Y. Effects of relative humidity and ionic liquids on the water content and glass transition of plasticized starch. Carbohydr. Polym. 2013, 97, 665-675. [CrossRef]

21. Lu, D.R.; Xiao, C.M.; Xu, S.J. Starch-based completely biodegradable polymer materials. Express Polym. Lett. 2009, 3, 366-375. [CrossRef]

22. Kabir, E.; Kaur, R.; Lee, J.; Kim, K.-H.; Kwon, E.E. Prospects of biopolymer technology as an alternative option for non-degradable plastics and sustainable management of plastic wastes. J. Clean. Prod. 2020, 258, 120536. [CrossRef]

23. Andrady, A.L.; Neal, M.A. Applications and societal benefits of plastics. Philos. Trans. R. Soc. B Biol. Sci. 2009, 364, 1977-1984. [CrossRef]

24. European Bioplastics, Bioplastics Definition, Bioplastics. (n.d.) Available online: https://www.european-bioplastics.org/ bioplastics / (accessed on 1 June 2021).

25. European Bioplastics, Bioplastic Market Data 2019. Available online: https://docs.european-bioplastics.org/publications/ market_data / Report_Bioplastics_Market_Data_2019.pdf (accessed on 1 June 2021).

26. Vinet, L.; Zhedanov, A. A 'missing' family of classical orthogonal polynomials. J. Phys. A Math. Theor. 2011, 44. [CrossRef]

27. Philp, J. OECD Policies for Bioplastics in the Context of a Bioeconomy, 2013. Ind. Biotechnol. 2014, 10, 19-21. [CrossRef]

28. Jaworski, J. The Application of Biotecnology to Industrial Sustainability-A Primer. 2001. Available online: www.oecd.org/sti/ biotechnology (accessed on 1 June 2021).

29. OECD. The Bioeconomy to 2030: Designing a Polity Agenda; OECD: Paris, France, 2009.

30. OECD. Towards Green Growth; OECD Publ.: Paris, France, 2020; p. 144. [CrossRef]

31. European Commission. Bioplastics: Sustainable materials for building a strong and circular European bioeconomy. Res. Results Pack. 2017, 1-20. [CrossRef]

32. Sataloff, R.T.; Johns, M.M.; Kost, K.M. A Strategy for Smart, Sustainable and Inclusive Growth 2010. Available online: http: / / eur-lex.europa.eu/LexUriServ/LexUriServ.do?uri=COM:2010:2020:FIN:EN:PDF (accessed on 1 June 2021).

33. Sataloff, R.T.; Johns, M.M.; Kost, K.M. The CAP towards 2020: Meeting the Food, Natural Resources and Territorial Challenges of the Future 2010. Available online: https:/ / eur-lex.europa.eu/LexUriServ/LexUriServ.do?uri=COM:2010:0672:FIN:en:PDF (accessed on 1 June 2021).

34. European Commission. European Commission: Roadmap to a Resource Efficient Europe. 2011. Available online: https:/ /www.europarl.europa.eu/meetdocs/2009_2014/documents/com/com_com(2011)0571_/com_com(2011)0571_en. pdf (accessed on 1 June 2021).

35. Karan, H.; Funk, C.; Grabert, M.; Oey, M.; Hankamer, B.; Karan, H.; Funk, C.; Grabert, M.; Oey, M.; Hankamer, B. Green Bioplastics as Part of a Circular Bioeconomy. Trends Plant Sci. 2019, 24, 237-249. [CrossRef] [PubMed]

36. Mutha, N.H.; Patel, M.; Premnath, V. Plastics materials flow analysis for India. Resour. Conserv. Recycl. 2006, 47, 222-244. [CrossRef]

37. Wuni, I.Y.; Shen, Q.; Osei-Kyei, R. Scientometric review of global research trends on green buildings in construction journals from 1992 to 2018. Energy Build. 2019, 190, 69-85. [CrossRef]

38. Cabeza, L.F.; Chàfer, M.; Mata, É. Comparative Analysis of Web of Science and Scopus on the Energy Efficiency and Climate Impact of Buildings. Energies 2020, 13, 409. [CrossRef]

39. Van Eck, N.J.; Waltman, L. Software survey: VOSviewer, a computer program for bibliometric mapping. Science 2009, 84, 523-538. [CrossRef]

40. World Population Prospects-Population Division-United Nations. Available online: https://population.un.org/wpp/ Download/Standard/Population/ (accessed on 24 February 2021).

41. UNESCO. Perspectives on Emerging Issues 2015. Available online: https://en.unesco.org/sites/default/files/usr15_ perspectives_on_emerging_issues.pdf (accessed on 1 June 2021).

42. Beijing, A.E. Wissenschaft und Technologie in China; 2016.

43. Mol, A.; Liu, Y. Institutionalising cleaner production in China: The Cleaner Production Promotion Law. Int. J. Environ. Sustain. Dev. 2005, 4, 227. [CrossRef]

44. Mol, A.P.J.; He, G.; Zhang, L. Information Disclosure in Environmental Risk Management: Developments in China. J. Curr. Chin. Aff. 2011, 40, 163-192. [CrossRef]

45. Swaine, M.D. The 19th Party Congress and Chinese Foreign Policy. Available online: www.china.org.cn/english/features/49007. html (accessed on 1 June 2021). 
46. Fund, C.; El-Chichakli, B.; Patermann, C.; Dieckhoff, P. Bioeconomy Policy (Part II): Synopsis of National Strategies around the World 2015. Available online: https://biooekonomierat.de/fileadmin/international/Bioeconomy-Policy_Part-II.pdf (accessed on 1 June 2021).

47. Cao, C.; Suttmeier, R.P.; Simon, D.F. China's 15-year science and technology plan. Phys. Today 2006, 59, 38-43. [CrossRef]

48. USDA. USDA Biopreferred. 2020. Available online: https://biopreferred.gov/BioPreferred/ (accessed on 1 June 2021).

49. Shina, R. The National Bioeconomy Blueprint: Meeting Grand Challenges. Ind. Biotechnol. 2012, 8, 94-96. [CrossRef]

50. Hüttl, R.F. Bio-economy Innovation. Bio-economy Council Report 2010. Available online: https://biooekonomierat.de/fileadmin/ Publikationen/Englisch/bioeconomy_council_report_2010.pdf (accessed on 1 June 2021).

51. Hüttl, R.F. Internationalisation of Bio-Economy Research in Germany 2012. Available online: https://biooekonomierat.de/ fileadmin/Publikationen/Englisch/BOER_Recommendation05_internationalization.pdf (accessed on 1 June 2021).

52. Federal Ministry of Education and Research (BMBF). National Research Strategy BioEconomy 2030 Our Route towards a Biobased Economy. 2011. Available online: www.bmbf.de/pub/bioeconomy_2030.pdf (accessed on 1 June 2021).

53. Taniguchi, R. Resource Mobilization by "Strange Bedfellows": A Case Study of Biomass Nippon Strategy. In Proceedings of the 2018 Portland International Conference on Management of Engineering and Technology (PICMET), Honolulu, HI, USA, 19-23 August 2018; IEEE: New York, NY, USA, 2018; pp. 1-9. [CrossRef]

54. Mirasol, F. Japanese Bioplastics Advance: Japan Pushes for Renewable, ICIS Chem. Bus. 2010. Available online: www.icis.com/ Articles/2010/10/18/9401980/japanese-bioplastics-advance.html (accessed on 1 June 2021).

55. Chanprateep, S. Current trends in biodegradable polyhydroxyalkanoates. J. Biosci. Bioeng. 2010, 110, 621-632. [CrossRef] [PubMed]

56. MEXT. The 4th Science and Technology Basic Plan of Japan. 2011. Available online: http:/ /www.mext.go.jp/component/english/ _icsFiles/afieldfile/2012/02/22/1316511_01.pdf (accessed on 1 June 2021).

57. Agency, E.E. Annex 10-Spain country case study, European Environment Agency, Copenhagen 2011. Available online: https: / / www.eea.europa.eu/publications/blossom/annex-10-2014-spain-country (accessed on 1 June 2021).

58. Lainez, M.; González, J.M.; Aguilar, A.; Vela, C. Spanish strategy on bioeconomy: Towards a knowledge based sustainable innovation. New Biotechnol. 2018, 40, 87-95. [CrossRef]

59. Ministry of Science and Technology. National Biotechnology Development Strategy, Gov. India. 2007. Available online: http:/ / dbtindia.gov.in/about-us/strategy-nbds (accessed on 11 November 2020).

60. Department of Biotechnology Ministry of Science \& Technology. National Biotechnology Development Strategy 2015-2020, Gov. India. 2015. Available online: http:/ /dbtindia.gov.in/about-us/strategy-nbds (accessed on 12 January 2021).

61. Kamal, N. Bioeconomy Transformation Programme. Annual Report 2015. Available online: http://www.bioeconomycorporation. my/wp-content/uploads/2011/11/publications/BTP_AR_2015.pdf (accessed on 1 June 2021).

62. Arujanan, M.; Singaram, M. The biotechnology and bioeconomy landscape in Malaysia. New Biotechnol. 2018, 40, 52-59. [CrossRef]

63. Malaysian Bioeconomy Corporation, BioNexus Development. (n.d.) Available online: http://www.bioeconomycorporation.my/ bionexus-development/bionexus-status / overview/ (accessed on 1 June 2021).

64. Imbert, E.; Ladu, L.; Tani, A.; Morone, P. The transition towards a bio-based economy: A comparative study based on social network analysis. J. Environ. Manag. 2019, 230, 255-265. [CrossRef]

65. Bonaccorso, M. SPRING-Italian Circular Bioeconomy Cluster European Cluster Collaboration Platform 2012. Available online: https:/ / clustercollaboration.eu/content/spring-italian-circular-bioeconomy-cluster (accessed on 2 March 2021).

66. Wibowo, E. Bioenergy Development in Indonesia, Ministry of Energy and Mineral Resources Republic of Indonesia 2014. p. 9. Available online: https:/ / www.iea.org/media/technologyplatform/workshops/southeastasiabioenergy2014/Indonesia.pdf (accessed on 1 June 2021).

67. German Bioeconomy Council. Bioeconomy Indonesia; German Bioeconomy Council: Berlin, Germany, 2015.

68. National Innovation Agency. National Innovation Agency (NIA) as Thailand's Bioplastics Focal Point 2012. Available online: www.bio-based.eu/iBIB (accessed on 1 June 2021).

69. Birch, K. Emergent Imaginaries and Fragmented Policy Frameworks in the Canadian Bio-Economy. Sustainability 2016, 8, 1007. [CrossRef]

70. BioteCanada. The Canadian Blueprint: Beyond Moose \& Mountains. In How We Can Build the World's Leading Bio-Based Economy, Canada; BioteCanada: Ottawa, ON, Canada, 2009.

71. Victoria, B.C. Bio-Economy, 2011th ed.; Ministry of Jobs, Tourism and Innovation: Ottawa, ON, Canada, 2012. Available online: https:/ / fsjpl.bibliocommons.com/v2/record/S49C126905441 (accessed on 1 June 2021).

72. Staffas, L.; Gustavsson, M.; McCormick, K.; Staffas, L.; Gustavsson, M.; McCormick, K. Strategies and Policies for the Bioeconomy and Bio-Based Economy: An Analysis of Official National Approaches. Sustainability 2013, 5, 2751-2769. [CrossRef]

73. Binder, D. Canada 1. In Olympic Education; Routledge: New York, NY, USA, 2017; pp. 104-118. [CrossRef]

74. Mohanty, A.K.; Misra, M.; Drzal, L.T. Sustainable Bio-Composites from Renewable Resources: Opportunities and Challenges in the Green Materials World. J. Polym. Environ. 2002, 10, 19-26. [CrossRef]

75. Nagarajan, V.; Mohanty, A.K.; Misra, M. Perspective on Polylactic Acid (PLA) based Sustainable Materials for Durable Applications: Focus on Toughness and Heat Resistance. ACS Sustain. Chem. Eng. 2016, 4, 2899-2916. [CrossRef] 
76. Jerez, A.; Partal, P.; Martínez, I.; Gallegos, C.; Guerrero, A. Rheology and processing of gluten based bioplastics. Biochem. Eng. J. 2005, 26, 131-138. [CrossRef]

77. Jerez, A.; Partal, P.; Martínez, I.; Gallegos, C.; Guerrero, A. Egg white-based bioplastics developed by thermomechanical processing. J. Food Eng. 2007, 82, 608-617. [CrossRef]

78. Accinelli, C.; Saccà, M.L.; Mencarelli, M.; Vicari, A. Deterioration of bioplastic carrier bags in the environment and assessment of a new recycling alternative. Chemosphere 2012, 89, 136-143. [CrossRef] [PubMed]

79. Accinelli, C.; Saccà, M.L.; Batisson, I.; Fick, J.; Mencarelli, M.; Grabic, R. Removal of oseltamivir (Tamiflu) and other selected pharmaceuticals from wastewater using a granular bioplastic formulation entrapping propagules of Phanerochaete chrysosporium. Chemosphere 2010, 81, 436-443. [CrossRef]

80. Van Soest, J.J.G.; Knooren, N. Influence of glycerol and water content on the structure and properties of extruded starch plastic sheets during aging. J. Appl. Polym. Sci. 1997, 64, 1411-1422. [CrossRef]

81. Judawisastra, H.; Sitohang, R.D.R.; Marta, L. Mardiyati Water absorption and its effect on the tensile properties of tapioca starch/polyvinyl alcohol bioplastics. IOP Conf. Series: Mater. Sci. Eng. 2017, 223, 012066. [CrossRef]

82. Khuenkeao, T.; Petchwattana, N.; Covavisaruch, S. Thermal and mechanical properties of bioplastic poly(lactic acid) compounded with silicone rubber and talc. AIP Conf. Proc. 2016, 1713, 80005. [CrossRef]

83. Mai, F.; Tu, W.; Bilotti, E.; Peijs, T. Preparation and properties of self-reinforced poly(lactic acid) composites based on oriented tapes. Compos. Part A Appl. Sci. Manuf. 2015, 76, 145-153. [CrossRef]

84. Gonzalez-Gutierrez, J.; Partal, P.; García-Morales, M.; Gallegos, C. Effect of processing on the viscoelastic, tensile and optical properties of albumen/starch-based bioplastics. Carbohydr. Polym. 2011, 84, 308-315. [CrossRef]

85. Wibowo, A.; Misra, M.; Park, H.-M.; Drzal, L.T.; Schalek, R.; Mohanty, A.K. Biodegradable nanocomposites from cellulose acetate: Mechanical, morphological, and thermal properties. Compos. Part A Appl. Sci. Manuf. 2006, 37, 1428-1433. [CrossRef]

86. Mohanty, A.K.; Tummala, P.; Liu, W.; Misra, M.; Mulukutla, P.V.; Drzal, L.T. Injection Molded Biocomposites from Soy Protein Based Bioplastic and Short Industrial Hemp Fiber. J. Polym. Environ. 2005, 13, 279-285. [CrossRef]

87. Hao, Y.; Yang, H.; Zhang, H.; Zhang, G.; Bai, Y.; Gao, G.; Dong, L. Diethylene glycol monobutyl ether adipate as a novel plasticizer for biodegradable polylactide. Polym. Bull. 2016, 73, 3143-3161. [CrossRef]

88. Wei, L.; Guho, N.M.; Coats, E.R.; McDonald, A.G. Characterization of poly(3-hydroxybutyrate-co-3-hydroxyvalerate) biosynthesized by mixed microbial consortia fed fermented dairy manure. J. Appl. Polym. Sci. 2014, 131. [CrossRef]

89. Papong, S.; Malakul, P.; Trungkavashirakun, R.; Wenunun, P.; Chom-In, T.; Nithitanakul, M.; Sarobol, E. Comparative assessment of the environmental profile of PLA and PET drinking water bottles from a life cycle perspective. J. Clean. Prod. 2014, 65, 539-550. [CrossRef]

90. Jiang, Y.; Marang, L.; Tamis, J.; van Loosdrecht, M.C.; Dijkman, H.; Kleerebezem, R. Waste to resource: Converting paper mill wastewater to bioplastic. Water Res. 2012, 46, 5517-5530. [CrossRef] [PubMed]

91. Verbeek, C.J.R.; Berg, L.V.D. Extrusion Processing and Properties of Protein-Based Thermoplastics. Macromol. Mater. Eng. 2010, 295, 10-21. [CrossRef]

92. Van Soest, J.J.G.; Kortleve, P.M. The influence of maltodextrins on the structure and properties of compression-molded starch plastic sheets. J. Appl. Polym. Sci. 1999, 74, 2207-2219. [CrossRef]

93. Lörcks, J. Properties and applications of compostable starch-based plastic material. Polym. Degrad. Stab. 1998, 59, 245-249. [CrossRef]

94. Park, H.-M.; Misra, M.; Drzal, A.L.T.; Mohanty, A.K. Green Nanocomposites from Cellulose Acetate Bioplastic and Clay: Effect of Eco-Friendly Triethyl Citrate Plasticizer. Biomacromolecules 2004, 5, 2281-2288. [CrossRef]

95. Chung, Y.-L.; Olsson, J.V.; Li, R.; Frank, C.W.; Waymouth, R.; Billington, S.L.; Sattely, E.S. A Renewable Lignin-Lactide Copolymer and Application in Biobased Composites. ACS Sustain. Chem. Eng. 2013, 1, 1231-1238. [CrossRef]

96. Fernandez, J.G.; Ingber, D.E. Manufacturing of Large-Scale Functional Objects Using Biodegradable Chitosan Bioplastic. Macromol. Mater. Eng. 2014, 299, 932-938. [CrossRef]

97. Mekonnen, T.; Mussone, P.G.; Khalil, H.; Bressler, D.C. Progress in bio-based plastics and plasticizing modifications. J. Mater. Chem. A 2013, 1, 13379-13398. [CrossRef]

98. Nogales, J.; Palsson, B.; Thiele, I. A genome-scale metabolic reconstruction of Pseudomonas putida KT2440: iJN746 as a cell factory. BMC Syst. Biol. 2008, 2, 79. [CrossRef]

99. Opgenorth, P.H.; Korman, T.P.; Bowie, J.U. A synthetic biochemistry module for production of bio-based chemicals from glucose Nat. Chem. Biol. 2016, 12, 393-395. [CrossRef]

100. Andreeßen, B.; Steinbüchel, A. Biosynthesis and Biodegradation of 3-Hydroxypropionate- Containing Polyesters. Appl. Environ. Microbiol. 2010, 76, 4919-4925. [CrossRef]

101. Emadian, S.M.; Onay, T.T.; Demirel, B. Biodegradation of bioplastics in natural environments. Waste Manag. 2017, 59, 526-536. [CrossRef] [PubMed]

102. Bhardwaj, R.; Mohanty, A.K.; Drzal, L.T.; Pourboghrat, A.F.; Misra, M. Renewable Resource-Based Green Composites from Recycled Cellulose Fiber and Poly(3-hydroxybutyrate-co-3-hydroxyvalerate) Bioplastic. Biomacromolecules 2006, 7, $2044-2051$. [CrossRef] [PubMed]

103. Rujnić-Sokele, M.; Pilipović, A. Challenges and opportunities of biodegradable plastics: A mini review. Waste Manag. Res. 2017, 35, 132-140. [CrossRef] 
104. Grothe, E.; Moo-Young, M.; Chisti, Y. Fermentation optimization for the production of poly( $\beta$-hydroxybutyric acid) microbial thermoplastic. Enzym. Microb. Technol. 1999, 25, 132-141. [CrossRef]

105. Moldes, C.; García, P.; García, J.L.; Prieto, M.A.; Moldes, C.; García, P.; García, J.L.; Prieto, M.A. In Vivo Immobilization of Fusion Proteins on Bioplastics by the Novel Tag BioF. Appl. Environ. Microbiol. 2004, 70, 3205-3212. [CrossRef]

106. Zhang, Y.; Cai, J.; Shang, X.; Wang, B.; Liu, S.; Chai, X.; Tan, T.; Wen, T. A new genome-scale metabolic model of Corynebacterium glutamicum and its application. Biotechnol. Biofuels 2017, 10, 1-16. [CrossRef] [PubMed]

107. Zhou, S.; Causey, T.B.; Hasona, A.; Shanmugam, K.T.; Ingram, L.O. Production of Optically Pure d -Lactic Acid in Mineral Salts Medium by Metabolically Engineered Escherichia coli W3110. Appl. Environ. Microbiol. 2003, 69, 399-407. [CrossRef] [PubMed]

108. Nguyen, H.T.H.; Qi, P.; Rostagno, M.; Feteha, A.; Miller, S.A. The quest for high glass transition temperature bioplastics. J. Mater. Chem. A 2018, 6, 9298-9331. [CrossRef]

109. Byaruhanga, Y.B.; Emmambux, M.N.; Belton, P.S.; Wellner, N.; Ng, A.K.G.; Taylor, J.R.N. Alteration of Kafirin and Kafirin Film Structure by Heating with Microwave Energy and Tannin Complexation. J. Agric. Food Chem. 2006, 54, 4198-4207. [CrossRef] [PubMed]

110. Eerhart, A.J.J.E.; Faaij, A.P.C.; Patel, M.K. Replacing fossil based PET with biobased PEF; process analysis, energy and GHG balance. Energy Environ. Sci. 2012, 5, 6407-6422. [CrossRef]

111. Tovar, C.D.G.; Colonia, B.S.O. Producción y procesamiento del maíz en Colombia. Rev. Guillermo Ockham 2013, 11, 97. [CrossRef]

112. Galvéz Arévalo, A.G. Elaboración de Plástico Biodegradable a Partir del Almidón Extraido de Maíz (Zea Mays) 2016. Available online: http:/ / www.repositorio.usac.edu.gt/5102/1/Ana\%20Gabriela\%20G\%C3\%A1lvez\%20Ar\%C3\%A9valo.pdf (accessed on 1 June 2021).

113. Hempel, F.; Bozarth, A.S.; Lindenkamp, N.; Klingl, A.; Zauner, S.; Linne, U.; Steinbüchel, A.; Maier, U.G. Microalgae as bioreactors for bioplastic production. Microb. Cell Factories 2011, 10, 81. [CrossRef]

114. Hiroe, A.; Tsuge, K.; Nomura, C.T.; Itaya, M.; Tsuge, T. Rearrangement of Gene Order in thephaCABOperon Leads to Effective Production of Ultrahigh-Molecular-Weight Poly[(R)-3-Hydroxybutyrate] in Genetically Engineered Escherichia coli. Appl. Environ. Microbiol. 2012, 78, 3177-3184. [CrossRef]

115. Mergaert, J.; Swings, J. Biodiversity of microorganisms that degrade bacterial and synthetic polyesters. J. Ind. Microbiol. Biotechnol. 1996, 17, 463-469. [CrossRef]

116. Júnior, W.G.M.; Gorgich, M.; Corrêa, P.; Martins, A.A.; Mata, T.M.; Caetano, N.S. Microalgae for biotechnological applications: Cultivation, harvesting and biomass processing. Aquaculture 2020, 528, 735562. [CrossRef]

117. Murariu, M.; Dubois, P.; Murariu, M.; Dubois, P. PLA composites: From production to properties. Adv. Drug Deliv. Rev. 2016, 107, 17-46. [CrossRef] [PubMed]

118. Wu, C.-S. Renewable resource-based composites of recycled natural fibers and maleated polylactide bioplastic: Characterization and biodegradability. Polym. Degrad. Stab. 2009, 94, 1076-1084. [CrossRef] 